OPEN ACCESS

Edited by:

Alice Newton

University of Algarve, Portugal

Reviewed by:

Paolo Magni,

National Research Council (CNR), Italy

Michael Joseph Ahrens,

Universidad de Bogotá Jorge Tadeo

Lozano, Colombia

*Correspondence:

Annamaria Volpi Ghirardini

voghi@unive.it

tORCID:

Annamaria Volpi Ghirardini orcid.org/0000-0002-8834-2595

Specialty section:

This article was submitted to

Conservation,

a section of the journal

Frontiers in Ecology and Evolution

Received: 30 September 2019

Accepted: 26 June 2020

Published: 17 July 2020

Citation:

Picone M, Delaney E,

Tagliapietra D, Guarneri I and

Volpi Ghirardini A (2020)

Bioaccumulation of Polychlorinated

Dibenzo-p-Dioxins (PCDDs)

and Dibenzofurans (PCDFs)

in Hediste diversicolor (Polychaeta: Nereididae). Front. Ecol. Evol. 8:235.

doi: 10.3389/fevo.2020.00235

\section{Bioaccumulation of Polychlorinated Dibenzo-p-Dioxins (PCDDs) and Dibenzofurans (PCDFs) in Hediste diversicolor (Polychaeta: Nereididae)}

\author{
Marco Picone', Eugenia Delaney¹, Davide Tagliapietra², Irene Guarneri² and \\ Annamaria Volpi Ghirardini ${ }^{*}+$
}

'Dipartimento di Scienze Ambientali, Informatica e Statistica, Università Ca' Foscari, Venezia, Italy, ${ }^{2}$ Consiglio Nazionale delle Ricerche, Istituto di Scienze Marine, Venezia, Italy

The effectiveness and reliability of the polychaete Hediste diversicolor (O.F. Müller, 1776) to bioaccumulate polychlorinated dibenzo-p-dioxins (PCDDs) and dibenzofurans (PCDFs) was assessed in an in-situ passive biomonitoring study. Field collected specimens were sampled in five sites within the Venice Lagoon (Italy), selected along a PCDD/F contamination gradient. The homolog profiles in the tissues of the common ragworm were considerably different from those observed in the sediments, independent of sediment contamination. Moreover, $H$. diversicolor accumulated preferentially the less chlorinated 2,3,7,8-TCDD, 2,3,7,8-TCDF and 2,3,4,7,8-PeCDF compared to the more chlorinated and hydrophobic hexa-, hepta- and octasubstituted congeners, as evidenced by the significant and linearly decreasing trend of the Biota-to-Sediment Accumulation Factor (BSAF) with the increasing lipophilicity of the congeners, expressed as the logarithmic form of the octanol/water partition coefficient (log $\left.\mathrm{K}_{\mathrm{OW}}\right)$. The BSAFs for dioxins and furans were generally low compared to other organochlorine compounds such as polychlorinated biphenyls and organochlorine pesticides, suggesting that $H$. diversicolor may eliminate both dioxins and furans efficiently.

Keywords: Venice Lagoon, TCDD, TCDF, benthos, bioaccumulators

\section{INTRODUCTION}

Polychlorinated dibenzo-p-dioxins (PCDDs) and dibenzofurans (PCDFs) are highly persistent, bioaccumulative and toxic contaminants not intentionally produced, but occurring in the environment as byproducts of chemical processes involving the use of chlorine (i.e., wood pulp and magnesium industries), as a result of combustion processes from both natural (forest fires) and anthropogenic sources (smoke from incinerators, car and boat exhaust fumes) or as impurities in chemicals (i.e., pesticides and herbicides) (Swerev and Ballschmiter, 1989).

Once released, $\mathrm{PCDD} / \mathrm{F}$ enter the marine and coastal environments via atmospheric deposition, riverine inputs from the inland, and direct discharges of urban and industrial wastewaters into the coastal waters (Armitage et al., 2009). 
In the marine environment PCDD/F are quickly adsorbed onto suspended matter, due to their high hydrophobicity, and then deposited onto the sediment where they accumulate over time, due to their persistence. As a consequence, sediment may act both as a secondary source of $\mathrm{PCDD} / \mathrm{F}$ pollution for the water column (Khairy et al., 2016) and as a primary source of contamination for the benthic species living and/or feeding on sediment-bound contaminants (Pruell et al., 1993, 2000).

Polychaetes are a major component of the coastal and estuarine systems, where they may represent up to $40 \%$ of the taxa constituting the communities (Amiard-Triquet et al., 2013). Many species living in soft-bottom habitats are endobenthic and occupy several ecological niches, serving as relevant vectors for the recycling of the detritus, as primary consumers of benthic algae and predators of other invertebrates, and as food for the organisms at the top of the benthic and aquatic trophic webs (Scaps, 2002; Dean, 2008; Amiard-Triquet et al., 2013).

Close contact with the sediment as well as detritivorous habits of most species make polychaetes vulnerable to the uptake of contaminants through both contact with dissolved chemicals and ingestion of pollutants bound to sediment particles or adsorbed onto detritus particles (Dean, 2008). Consequently, contaminants accumulated into the tissues of the polychaetes may then be transferred to higher levels of the trophic web, leading to possible biomagnification phenomena (Ruus et al., 2012; Sizmur et al., 2013). For these reasons, polychaetes are often used in ecotoxicological studies to assess both early warning signals of chemical stress, by using relevant biomarkers, and the bioavailability of the contaminants (Durou et al., 2007a,b; Nesto et al., 2010; Ruus et al., 2012; Amiard-Triquet et al., 2013).

A commonly used polychaete species in ecotoxicological research is the common ragworm Hediste diversicolor (O.F. Müller, 1776). This burrowing polychaete is omnivorous, but also behaves as a deposit feeder, by collecting detritus near the opening of its burrows, and is widespread in the shallow marine and estuarine waters of the European coasts of the Atlantic, the Mediterranean Sea, the Black Sea and the Caspian Sea (Scaps, 2002). Its large dispersion into brackish waters has favored its frequent use as a biological indicator for assessing exposure and effects of sediment-bound contaminants in estuaries and coastal lagoons affected by pollution due to anthropogenic sources, including metals (Volpi Ghirardini et al., 1999; Berthet et al., 2003; Frangipane et al., 2005) and organic contaminants, such as polynuclear aromatic hydrocarbons (PAHs) - although the ability of polychaetes to biotransform PAHs was demonstrated (Jørgensen et al., 2008) and polychlorinated biphenyls (PCBs) (Gunnarsson et al., 1999; Cornelissen et al., 2006; Langston et al., 2012). Nevertheless, the ability of $H$. diversicolor to also accumulate other persistent and bioaccumulative toxicants, as PCDD/F, has been rarely explored, although these polychlorinated compounds may accumulate in fish - and also humans (Raccanelli et al., 2007) - through the marine and estuarine trophic web, where $H$. diversicolor represents a relevant trophic link (Nunes et al., 2011).

The present study examined the effectiveness and reliability of $H$. diversicolor as an indicator of exposure for PCDD/F in an in-situ passive biomonitoring study, using field-collected polychaetes. The Venice Lagoon was chosen as a case study since sources, inputs and sediment concentration of PCDD/F have been extensively studied in the past decades (Fattore et al., 1997; Marcomini et al., 1997; Jimenez et al., 1998; Bellucci et al., 2000; Frignani et al., 2001a). The aims of the study were the assessment of possible bioaccumulation in tissues of $H$. diversicolor, the identification of the congeners with higher ability to accumulate into polychaete tissues, and the analysis of the possible relationships between accumulation and the lipophilicity (expressed as $\log \mathrm{K}_{\mathrm{OW}}$ ) of the 2,3,7,8 chlorinated congeners.

The results of this study, performed in 1998, are presented only now because we found that in the last 20 years no significant progress has been made in the field of bioaccumulation of organochlorine compounds in estuarine environments. Although they play a relevant role in the trophic webs of marine and estuarine environments, benthic infaunal organisms such as polychaetes, have been too often disregarded as bioindicators for bioavailability/bioaccessibility of PCDD/Fs, in favor of other species of greater commercial interest (fish and molluscs). The focal purpose of this paper is thus to underline how these organisms are suitable for studying bioaccumulation of organic contaminants (other than PAHs), as well as to promote a more widespread exploitation of polychaetes in monitoring programs.

\section{MATERIALS AND METHODS}

\section{Study Area}

The Venice Lagoon is one of the largest and relevant Coastal Transitional Ecosystems of the Mediterranean (Tagliapietra et al., 2009); it is about $50 \mathrm{~km}$ long and $10 \mathrm{~km}$ wide, accounting for a surface of about $550 \mathrm{~km}^{2}$. Out of them, $36 \mathrm{~km}^{2}$ are salt marshes, $30 \mathrm{~km}^{2}$ islands (excluding the barrier islands) and the rest is covered by water. The mean depth of the water column is about $1.2 \mathrm{~m}$, with only $5 \%$ of the lagoon deeper than $5 \mathrm{~m}$ (Molinaroli et al., 2009). The volume of water contained in the lagoon is about 628 million $\mathrm{m}^{3}$, and according to Kjerfve (1994), the Venice Lagoon can be defined as a "restricted" coastal lagoon. The basin is connected to the Adriatic Sea through three inlets (Lido, Malamocco, and Chioggia) which allow tidal flushing twice a day (microtidal and predominantly semidiurnal tides) (Tagliapietra and Volpi Ghirardini, 2006). Every day the Venice Lagoon exchanges with the Adriatic Sea about 400 million $\mathrm{m}^{3}$ of water while the inflow from the inland through the rivers and subsoil averages 3.7 million $\mathrm{m}^{3}$ (Bernstein and Montobbio, 2011). The drainage basin is about $1850 \mathrm{~km}^{2}, 40 \%$ of which is reclaimed land lying under the sea level.

The primary source of pollution is the Porto Marghera industrial district (Bellucci et al., 2000; Frignani et al., 2001a,b; Zonta et al., 2007). Other point and non-point sources of pollution flowing into the lagoon include also treated and untreated municipal wastewaters, streams, agricultural runoff, boat traffic and atmospheric deposition (Guerzoni et al., 2004; Secco et al., 2005; Volpi Ghirardini et al., 2005; Gambaro et al., 2009). The recorded pattern of pollution follows the urban and industrial development: evidence exists that 
contamination of waters and sediments started in 1920 with the development of the first part of the industrial area, then accelerated after 1933 and again after World War II (Frignani et al., 2001a,b). As a consequence, the contamination gradient was largely superimposed on the inland-sea transect (Picone et al., 2016, 2018).

The atmospheric and riverine inputs of $\mathrm{PCDD} / \mathrm{F}$ into the Venice Lagoon has been estimated in the order of 2.2-195.7 $\mathrm{g}$ $\mathrm{y}^{-1}$ (Guerzoni et al., 2007) and $6.9 \mathrm{~g} \mathrm{y}^{-1}$ (Bettiol et al., 2005), respectively; the contribution of treated and untreated discharges from the industrial district of Porto Marghera has been estimated in $0.10-0.26 \mathrm{~g} \mathrm{y}^{-1}$ as toxicity equivalents (MAG. ACQUE-Uta, 2011).

\section{Sediment and Polychaete Sampling}

Sediment and polychaete samples were collected during summer 1998 from 5 sub-tidal shallows, selected along a gradient of chemical contamination and affected by different sources of pollution (Figure 1). Palude della Centrega (CE) is an inter-tidal mudflat in the northern basin of the Lagoon, chosen as possible reference site due to the low concentrations of contaminants characterizing the area (Volpi Ghirardini et al., 2005; Picone et al., 2008). Dese river (DE) and Osellino canal (OS) sites are two estuaries influenced by agricultural runoff; OS is also characterized by multi-sources pollution being affected by both urban and industrial discharges, due to the proximity to the urban area of Mestre and the illegal landfill of Campalto (Critto et al., 2003). Canale Industriale Sud (SA) and Canale LusoreBrentelle (BR) are two industrial canals located within the Porto Marghera district; in particular, site BR is a polluted site both as concern metals and organic micropollutants (Volpi Ghirardini et al., 2005; Bellucci et al., 2009; Picone et al., 2018) catching also freshwater from the Naviglio di Brenta canal.

Sediment sampling was performed following the integrated design and Quality Assurance/Quality Control (QA/QC) procedures reported in Volpi Ghirardini et al. (2005). Briefly, in each site, the sampling area was defined as a circle with a diameter of $30 \mathrm{~m}$. Within this area, eight sediment cores (depth $0-20 \mathrm{~cm}$, diameter $5 \mathrm{~cm}$ ) were collected with a Plexiglas ${ }^{\circledR}$ corer and then pooled to obtain an integrated sample. This procedure was performed in triplicate in each sampling area. Sediment samples were stored in 21 glass containers and kept refrigerated until their arrival in the laboratory. Samples were processed within 2 weeks, according to ASTM guidelines (ASTM, 2014).

Polychaetes were collected within sediment sampling areas using a box corer $(14 \times 14 \times 16 \mathrm{~cm})$. Sediments collected with the box corer were washed into polyethylene tanks and then the sediment slurry was poured into a $1 \mathrm{~mm}$ mesh size sieve and thoroughly washed in situ with seawater to separate the worms from the substrate. Once collected, the polychaetes were placed in 1 liter polyethylene containers filled with a layer of clean quartz sand (grain size approx. 60-100 $\mu \mathrm{m}$ ) and natural seawater, in order to minimize the stress during the transport in the laboratory. A variable number of polychaetes was retrieved in each site, from 30 up to 80 depending on the population density in the area. Only for sites BR and OS it was possible to obtain three replicates with sufficient biological material for analysis; as a consequence, it was necessary to pool organisms collected in each site in order to have enough biological material for performing chemical analysis with an adequate limit of detection (0.25 $\left.\mathrm{pg} \mathrm{g}^{-1} \mathrm{dw}\right)$.

\section{Sediment Analysis}

Total organic carbon (TOC) analyses were performed using a CHNS-O analyzer on aliquots of $10-20 \mathrm{mg}$ of dry sediment acidified with $20-\mu \mathrm{L}$ of $1 \mathrm{~N} \mathrm{HCl}$ solution and dried at $105^{\circ} \mathrm{C}$ for $15 \mathrm{~min}$. Sediment grain-size was determined following a gravimetric procedure and was subsequently classified according to Shepard (1954). PCDD/F in the sediments were analyzed according to the procedure reported in Bellucci et al. (2000), based on the United States. EPA method 1613/94 for the determination of 17 congeners 2,3,7,8 substituted of dioxins and furans using gas chromatography-mass spectrometry (GC-MS). One composite sample $(n=1)$ per site was analyzed.

\section{Polychaete Holding and Analysis}

Once in the laboratory, the polychaetes were depurated for 4 days in small glass aquaria $(20 \times 20 \times 15 \mathrm{~cm})$ containing acid-washed quartz sand and artificial seawater (1:1 v/v sand/water ratio), to allow the elimination of the gut's content. Then, they were transferred for 1 day in aquaria containing only artificial seawater, to remove also the quartz sand accumulated during depuration phase (Lobel et al., 1991; Volpi Ghirardini et al., 1999). Artificial seawater was prepared by dissolving an artificial sea salt mixture (Ocean Fish ${ }^{\circledR}$, PRODAC International, Cittadella, Italy) in Milli$\mathrm{Q}^{\circledR}$ purified water.

Depuration was carried out under constant aeration, at a temperature of $18^{\circ} \mathrm{C}$ and salinity of $20 \mathrm{psu}$; overlying water was renewed every 48 - $\mathrm{h}$ and the fecal pellets were removed daily, to avoid the ingestion by the worms and the consequent failure of the gut cleaning. Temperature, salinity and ammonia were checked daily.

During the last day of depuration in seawater, glass tubes were introduced into the aquaria to allow polychaetes to individually settle in there, to avoid aggressive behavior, cannibalism and also damages due to the lack of substrate (e.g., autotomy). At the end of the depuration phase, animals were anaesthetized using a $10 \%$ ethanol solution in seawater $20 \%$ and individually checked for species confirmation under a dissecting microscope. After taxonomic confirmation and determination of biometric parameters (in order to select polychaetes of comparable age), pooled samples of 20-30 specimens per sampling site were frozen until the analysis. Taxonomic identification was performed in order to avoid mixing with specimens belonging to other species, such as Alitta succinea (Leuckhart, 1847) and Perinereis cultrifera (Grube, 1840), that may share the habitat with $H$. diversicolor (Volpi Ghirardini et al., 1999). $\mathrm{PCDD} / \mathrm{F}$ in the tissues were analyzed using the same method reported for sediments; prior to analysis, the frozen polychaete samples were freeze-dried. One composite sample $(n=1)$ per site was analyzed.

Lipids were extracted by Accelerated Solvent Extraction (ASE) with $50 \mathrm{ml}$ of $\mathrm{n}$-hexane/dichloromethane $50 / 05$ at $150^{\circ} \mathrm{C}, 1500$ psi 7-min heat-up and two cycles of 5 min static time. The extracts 


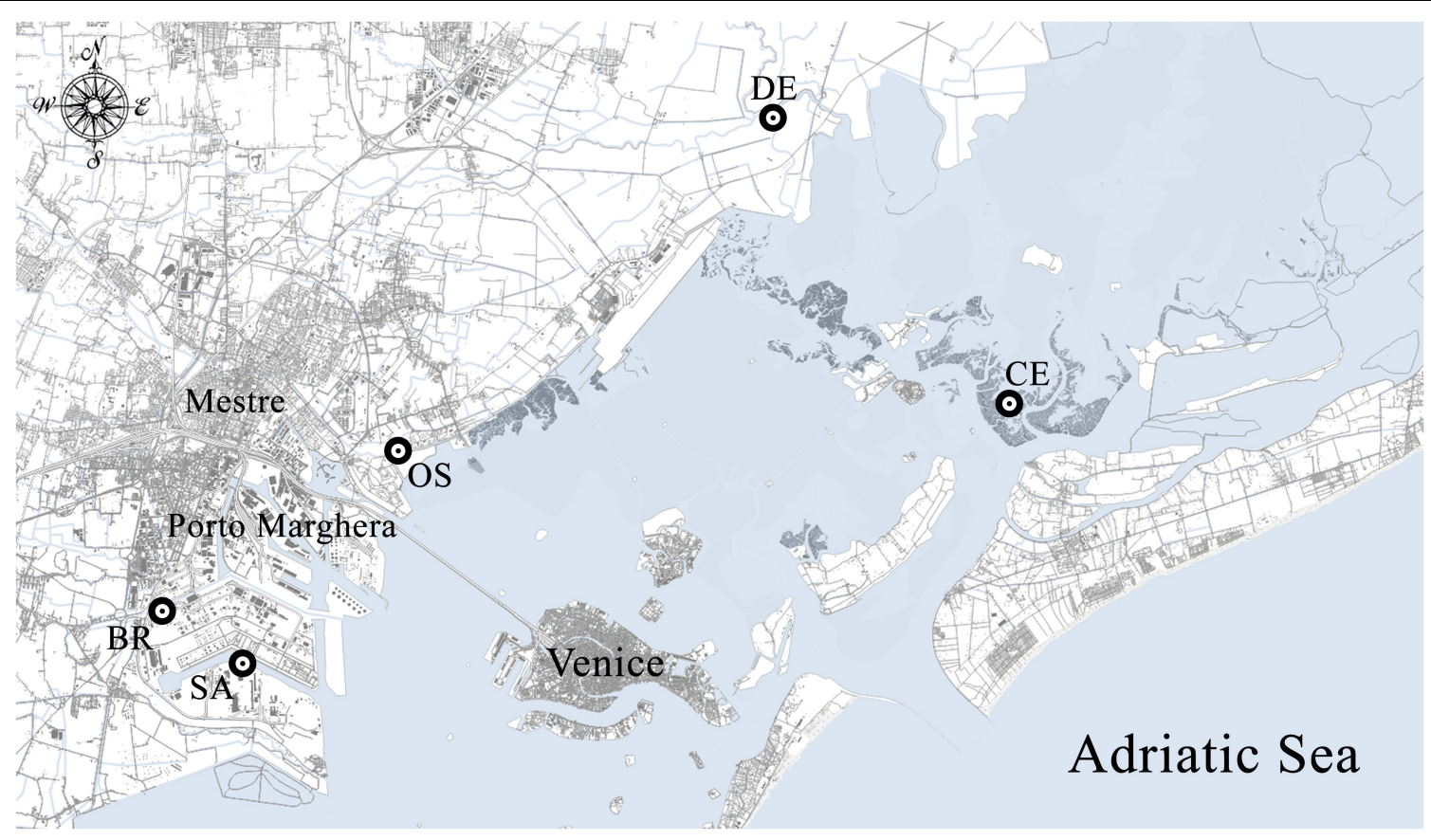

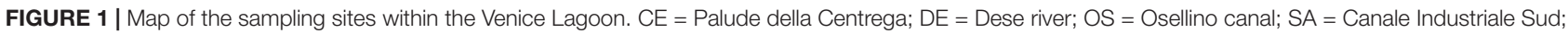
$\mathrm{BR}=$ Canale Lusore-Brentelle.

were desiccated using an evaporator equipped with a vacuum controller. The lipid content was then determined gravimetrically using an analytical balance.

\section{Data Elaboration and Analysis}

Concentrations of $\mathrm{PCDD} / \mathrm{F}$ in sediments and tissues were reported on dry weight $(\mathrm{dw})$ basis. The dry weight concentrations were then also converted in 2,3,7,8-TCDD equivalents by multiplying the sediment concentrations by the toxic equivalency factors (TEFs) proposed by the World Health Organization (Van den Berg et al., 2006). Cluster analysis was used to categorize the homolog profile of $\mathrm{PCDD} / \mathrm{F}$ in sediments and tissues; Euclidean distances and complete linkage were used as distance metric and joining rule, respectively. Before cluster analysis, sediment and tissue concentrations were transformed to per mil 2,3,7,8 chlorosubstituted homologs, by normalizing the sum of the isomers with the same degree of chlorination (i.e., PeCDD or HxCDD) to the sum of all dioxins and furans congeners with a concentration above the detection limit (Marcomini et al., 1997).

Spearman's non-parametric correlation was applied to test for significant correlations between sediment and tissue concentrations of the 17 congeners of PCDD/F, whilst linear regression was used to verify the linkage between BSAFs and the octanol-water partition coefficients $\left(\mathrm{K}_{\mathrm{OW}}\right)$, after logarithmic transformation. LogK $\mathrm{K}_{\mathrm{W}}$ values were taken from Chen et al. (2001).

Biota-Sediment Accumulation Factors (BSAFs) were calculated for each sampling site as the ratio of contaminant concentration in tissues (pg $\mathrm{g}^{-1} \mathrm{dw}$ ) on the contaminant concentration in sediments ( $p g \mathrm{~g}^{-1} \mathrm{dw}$ ), normalized to the lipid content and to the organic carbon content, respectively (Burkhard, 2009). For the calculation of BSAFs, concentrations below detection limits were assumed to equal a value half of the detection limit used. Welch's ANOVA and Games-Howell test were applied to the pooled BSAF data in order to check for the overall significant difference in the accumulation of the congeners of PCDD/F. Welch's ANOVA was chosen as a parametric method for the analysis of variance since homogeneity of variances condition was not met also after logarithmic and square root transformations.

All the statistical analysis were performed using the StatSoft Statistica v8.0 (Spearman's non-parametric correlation, linear regression) and IBM SPSS Statistics v.25 software (Welch's ANOVA and Games-Howell post hoc test).

\section{RESULTS}

\section{Sediment Chemistry}

Total organic carbon in the sediments ranged from $1.88 \%$ (CE) up to $4.67 \%$ (OS); grain size was characterized by a prevailing fraction of silt, ranging from $52.9 \%$ (BR) up to $69.6 \%$ (SA). According to the ternary classification of Shepard (1954) samples CE, DE, OS, and SA were classified as clayey silts, whilst sample BR was classified sandy silt.

Sediment PCDD/F concentrations at the five study sites ranged between 73 and $6,621 \mathrm{pg} \mathrm{g}^{-1} \mathrm{dw}$. The sediments collected at site SA $\left(6,621 \mathrm{pg} \mathrm{g}^{-1} \mathrm{dw}\right)$ were the most contaminated being characterized by total concentrations ( $\Sigma$ PCDD/F) of 1 or 2 order 
of magnitude higher than the other samples (Table 1). As concern dioxins, the total sediment concentrations ranged from $24 \mathrm{pg}$ $\mathrm{g}^{-1} \mathrm{dw}$ (CE) to $677 \mathrm{pg} \mathrm{g}^{-1} \mathrm{dw}$ (OS), with OCDD accounting for more than $75 \%$ of total dioxins in all samples; $2,3,7,8$-TCDD occurred at concentrations above the detection limit $\left(0.5 \mathrm{pg} \mathrm{g}^{-1}\right.$ $\mathrm{dw})$ only in sample SA (1 $\left.\mathrm{pg} \mathrm{g}^{-1} \mathrm{dw}\right)$. With regard to furans, the highest concentration was measured in sample SA (6061 pg $\mathrm{g}^{-1} \mathrm{dw}$ ) whilst the reference sample collected in site CE was, as expected, the least contaminated one $\left(47 \mathrm{pg} \mathrm{g}^{-1} \mathrm{dw}\right)$; the congeners detected at highest concentrations were $1,2,3,4,6,7,8$ HpCDF and 1,2,3,4,6,7,8,9-OCDDF.

The equivalent toxicity $\Sigma$ TE (WHO-TEQ) in the sediment samples ranged from $2 \mathrm{pg} \mathrm{g}^{-1} \mathrm{dw}$ (CE) to $60 \mathrm{pg} \mathrm{g}^{-1} \mathrm{dw}$ (SA) and showed the same gradient as the total concentrations: $\mathrm{CE}<\mathrm{DE}<\mathrm{BR}<<\mathrm{OS}<\mathrm{SA}$.

Homolog profiles in sediment showed different patterns among sites, especially as concern the contribution of OCDD and OCDF (Figure 2). In sample SA, the profile was dominated by OCDF and characterized by negligible contributions of the other homologs except for OCDD and HpCDF; in contrast, in samples BR and OS the profiles showed a dominance of OCDD over the more chlorinated furans. In DE and CE the profile was characterized by a gradient of increasing concentrations of $\mathrm{PCDD} / \mathrm{F}$ with increasing degree of chlorination, but with a dominance of OCDF over OCDD and HpCDF. Cluster analysis confirmed this categorization of samples into three groups (Figure 3).

\section{Tissue Analysis}

Polychaete tissues were characterized by a variable lipid concentration, ranging from 0.10 to $0.14 \mathrm{~g} \mathrm{~g}^{-1}$ of tissue, whilst organic carbon content averaged $0.53 \mathrm{~g} \mathrm{~g}^{-1}$ of tissue (range: $\left.0.52-0.54 \mathrm{~g} \mathrm{~g}^{-1}\right)$.

Real total concentration $(\Sigma \mathrm{PCDD} / \mathrm{F})$ in polychaete tissues ranged from $33 \mathrm{pg} \mathrm{g}^{-1} \mathrm{dw}$ (DE) up to $300 \mathrm{pg} \mathrm{g}^{-1} \mathrm{dw}$ (SA) (Table 1). The gradient of real total concentration was as follows: $\mathrm{DE}<\mathrm{CE}<\mathrm{OS}<\mathrm{BR}<\mathrm{SA}$. The concentrations of dioxins were quite homogeneous among the samples, ranging from 13 $\mathrm{pg} \mathrm{g}^{-1} \mathrm{dw}$ (DE) to $30 \mathrm{pg} \mathrm{g}^{-1} \mathrm{dw}$ (BR). In samples CE and DE only $1,2,3,7,8$-PCDD, $1,2,3,4,6,7,8$-HpCDD and OCDD occurred at concentrations above the detection limits $\left(0.25 \mathrm{pg} \mathrm{g}^{-1} \mathrm{dw}\right)$; this latter was also the congener exhibiting the highest concentration in all the samples. As observed in the sediments, 2,3,7,8-TCDD was detectable only in sample SA. Site DE also showed the lowest concentration of furans $\left(21 \mathrm{pg} \mathrm{g}^{-1} \mathrm{dw}\right)$, whilst the highest were detected in the tissues of the polychaetes sampled in the industrial canals BR (111 $\mathrm{pg} \mathrm{g}^{-1} \mathrm{dw}$ of furans) and SA (281 $\mathrm{pg} \mathrm{g}^{-1} \mathrm{dw}$ of furans). The congeners occurring at higher concentrations were 2,3,7,8-TCDF and 1,2,3,4,6,7,8,9-OCDF. Concentrations normalized to lipid content ranged from $268 \mathrm{pg} \mathrm{g}^{-1}$ lipids (DE) to $2111 \mathrm{pg} \mathrm{g}^{-1}$ lipids (SA).

The equivalent toxicity in the tissues ranged from 3 pg $\mathrm{g}^{-1} \mathrm{dw}$ (DE) to $26 \mathrm{pg} \mathrm{g}^{-1} \mathrm{dw}$ (SA); the gradient $(\mathrm{DE}<\mathrm{CE}<\mathrm{BR}<\mathrm{OS}<<\mathrm{SA})$ was slightly different from the one for total concentrations, since OS showed higher equivalent toxicity with respect to $\mathrm{BR}\left(10 \mathrm{pg} \mathrm{g}^{-1} \mathrm{dw}\right.$ vs. $\left.5 \mathrm{pg} \mathrm{g}^{-1} \mathrm{dw}\right)$, despite lower total concentration (104 $\mathrm{pg} \mathrm{g}^{-1} \mathrm{dw}$ vs. $141 \mathrm{pg} \mathrm{g}^{-1} \mathrm{dw}$ ).
Cluster analysis on homolog profiles evidenced the occurrence of distinct patterns of accumulation in the tissue (Figure 3). At site BR the polychaetes accumulated mostly OCDF and secondarily OCDD and TCDF, whereas the polychaetes collected at sites SA and OS accumulated primarily furans (contributing up to $87 \%$ and $94 \%$ to $\Sigma \mathrm{PCDD} / \mathrm{F}$, respectively), with a prevalence of HxCDF, TCDF and PeCDF, over the other furans and OCDD. The samples with less accumulation, DE and CE, showed a more heterogeneous pattern, with an accumulation of OCDD and less chlorinated PCDF (DE) or OCDD and more chlorinated PCDF (CE) (Figure 4). In any case, differences in homolog concentrations in these samples are very low.

\section{Comparison Between Sediments and Tissues}

No correlation was observed between PCDD congeners in the sediment and in the polychaete tissues $(p>0.05)$; in the case of furans, significant correlations (Spearman's $R>0.9$; $p<0.05$ ) were found for the PeCDFs, HpCDFs and two congeners of HxCDFs (namely, 1,2,3,4,7,8-HxCDF and 1,2,3,6,7,8-HxCDF). Spearman's correlation was not calculated for 2,3,7,8-TCDD and $1,2,3,7,8,9 \mathrm{HxCDD}$ due to the large number of data below detection limits.

Sediment Accumulation Factors value ranged between 0.003 (OCDF in site SA) and 11.13 (TCDF in site BR). Hepta- and octachlorinated congeners showed a BSAF about one order of magnitude lower than the less chlorinated congeners (Table $\mathbf{1}$ ).

Linear regression revealed a significant relationship with a decreasing trend between $\operatorname{logBSAF}$ and $\log \mathrm{K}_{\mathrm{Ow}}\left(F_{1,83}=43.878\right.$; $\left.r^{2}=0.289 ; r=-0.539 ; p<0.0001\right)$, indicating a tendency to accumulate preferentially the congeners with lower $\log \mathrm{K}_{\mathrm{OW}}$ (Figure 5).

Welch's ANOVA highlighted significant differences among the BSAFs calculated for the congeners $\left(F_{16,25}=6.108, p<0.001\right)$; Games-Howell test detected significant differences $(p<0.05)$ between 2,3,7,8-TCDF and several congeners (Figure 6).

\section{DISCUSSION}

The lack of replication did not allow to verify whether among-site differences are significant (especially for the less contaminated $\mathrm{CE}$ and DE samples) and may raise issues concerning the analytical variability of the data. However, specific contamination patterns emerged both in sediments and in polychaete tissues that are consistent with the underlying contamination gradient and other studies (Jimenez et al., 1998; MAG. ACQUE-Thetis, 2006, 2007; Picone, 2006), suggesting that analytical variability is of secondary relevance as compared with environmental variability of PCDD/F contamination in the Venice Lagoon.

\section{PCDD/F in the Sediments}

Sediment total concentrations and toxicity equivalents corroborated expectations for the underlying contamination gradient. The lowest concentration of PCDD/F were measured at the reference site $\mathrm{CE}$ and at the estuarine site $\mathrm{DE}$ located far from the industrial district, whilst the highest were observed within 
TABLE 1 | PCDDs and PCDFs concentrations in composite sediment samples, composite polychaetes samples and Biota-to-Sediment Accumulation Factors (BSAFs) calculated for the 17 congeners of 2,3,7,8 chlorosubstituted dioxins and furans.

\begin{tabular}{|c|c|c|c|c|c|c|c|c|c|c|c|c|c|c|c|}
\hline \multirow[t]{2}{*}{ Congener } & \multicolumn{5}{|c|}{ Sediment real concentration ( $\mathrm{pg} \mathrm{g}^{-1} \mathrm{dw}$ ) } & \multicolumn{5}{|c|}{ Tissue real concentration $\left(\mathrm{pg} \mathrm{g}^{-1} \mathrm{dw}\right)$} & \multicolumn{5}{|c|}{$\begin{array}{l}\text { Sediment concentration normalized to organic } \\
\text { carbon }\left(\mathrm{pg} \mathrm{g}^{-1} \mathrm{C}\right)\end{array}$} \\
\hline & BR & CE & $\mathrm{DE}$ & os & SA & BR & CE & DE & os & SA & BR & CE & DE & os & SA \\
\hline 2,3,7,8 TCDD & $<0.5$ & $<0.5$ & $<0.5$ & $<0.5$ & 1 & $<0.25$ & $<0.25$ & $<0.25$ & $<0.25$ & 1 & $<19$ & $<27$ & $<16$ & 11 & 29 \\
\hline $1,2,3,7,8$ PCDD & $<0.5$ & $<0.5$ & $<0.5$ & 2 & 4 & 1 & 2 & 1 & 2 & 2 & $<19$ & $<27$ & $<16$ & 51 & 95 \\
\hline $1,2,3,4,7,8 \mathrm{HxCDD}$ & $<0.5$ & $<0.5$ & $<0.5$ & 2 & 13 & 1 & 1 & 1 & 1 & 1 & $<19$ & $<27$ & $<16$ & 51 & 280 \\
\hline $1,2,3,6,7,8 \mathrm{HxCDD}$ & $<0.5$ & $<0.5$ & 1 & 4 & 7 & 1 & 2 & 1 & 1 & 2 & $<19$ & $<27$ & 39 & 84 & 150 \\
\hline $1,2,3,7,8,9 \mathrm{HxCDD}$ & $<0.5$ & $<0.5$ & 4 & $<0.5$ & $<0.5$ & 1 & 1 & 1 & 1 & 1 & $<19$ & $<27$ & 136 & 11 & 11 \\
\hline 1,2,3,4,6,7,8 HpCDD & 35 & 3 & 21 & 96 & 99 & 5 & 3 & 2 & 2 & 4 & 1,364 & 133 & 686 & 2,058 & 2,194 \\
\hline 1,2,3,4,6,7,8,9 OCDD & 194 & 20 & 87 & 571 & 435 & 22 & 10 & 9 & 8 & 9 & 7,519 & 1,059 & 2,816 & 12,227 & 9,603 \\
\hline 2,3,7,8 TCDF & $<0.5$ & $<0.5$ & 2 & 9 & 16 & 14 & 2 & 5 & 21 & 69 & $<19$ & $<27$ & 68 & 193 & 362 \\
\hline 1,2,3,7,8 PCDF & 6 & 2 & 3 & 19 & 66 & 3 & 2 & 3 & 13 & 28 & 225 & 96 & 107 & 400 & 1,464 \\
\hline $2,3,4,7,8$ PCDF & 3 & 1 & 1 & 9 & 15 & 4 & 2 & 2 & 9 & 22 & 101 & $<27$ & 36 & 197 & 336 \\
\hline $1,2,3,4,7,8 \mathrm{HxCDF}$ & 12 & 2 & 5 & 32 & 153 & 4 & 3 & 2 & 12 & 50 & 473 & 96 & 159 & 681 & 3,377 \\
\hline $1,2,3,6,7,8 \mathrm{HxCDF}$ & 4 & 1 & 2 & 15 & 65 & 2 & 2 & 1 & 5 & 17 & 151 & 59 & 78 & 323 & 1,426 \\
\hline $1,2,3,7,8,9 \mathrm{HxCDF}$ & 30 & $<0.5$ & $<0.5$ & 115 & 10 & 1 & 2 & 1 & 1 & 3 & 1,163 & $<27$ & $<16$ & 2,463 & 214 \\
\hline 2,3,4,6,7,8 HxCDF & 1 & $<0.5$ & 2 & 16 & 42 & 2 & 2 & 1 & 4 & 10 & 54 & $<27$ & 68 & 334 & 927 \\
\hline 1,2,3,4,6,7,8 HpCDF & 61 & 13 & 55 & 295 & 1,305 & 10 & 5 & 2 & 12 & 36 & 2,345 & 676 & 1,780 & 6,317 & 28,808 \\
\hline $1,2,3,4,7,8,9 \mathrm{HpCDF}$ & 9 & 3 & 5 & 17 & 192 & 2 & 2 & 1 & 3 & 11 & 357 & 133 & 175 & 373 & 4,238 \\
\hline $1,2,3,4,6,7,8,9$ OCDF & 143 & 26 & 141 & 198 & 4,197 & 68 & 15 & 3 & 9 & 34 & 5,543 & 1,399 & 4,563 & 4,240 & 92,649 \\
\hline$\Sigma P C D D$ & 232 & 25 & 115 & 677 & 560 & 31 & 19 & 13 & 14 & 19 & 8,981 & 1,324 & 3,725 & 14,493 & 12,362 \\
\hline$\Sigma \mathrm{PCDF}$ & 269 & 48 & 218 & 725 & 6,061 & 111 & 37 & 21 & 90 & 281 & 10,430 & 2,564 & 7,049 & 15,520 & 133,801 \\
\hline$\Sigma \mathrm{PCDD} / \mathrm{F}$ & 501 & 73 & 333 & 1,402 & 6,621 & 142 & 56 & 33 & 104 & 300 & 19,411 & 3,888 & 10,773 & 30,013 & 146,163 \\
\hline$\Sigma$ TE (WHO-TEQ) & 8 & 2 & 4 & 30 & 60 & 5 & 4 & 3 & 10 & 26 & 27 & 28 & 29 & 30 & 31 \\
\hline
\end{tabular}




\section{TABLE 1 | Continued}

\begin{tabular}{|c|c|c|c|c|c|c|c|c|c|c|c|c|}
\hline \multirow[t]{2}{*}{ Congener } & \multicolumn{5}{|c|}{ Tissue concentration normalized to lipid content ( $\mathrm{pg} \mathrm{g}^{-1}$ lipid) } & \multicolumn{5}{|c|}{ BSAF } & \multicolumn{2}{|c|}{ Spearman's correlation } \\
\hline & BR & CE & DE & os & SA & BR & CE & DE & os & SA & $\mathbf{R}$ & $\mathbf{p}$ \\
\hline 2,3,7,8 TCDD & 1 & 1 & 1 & 1 & 8 & $>0.10$ & $>0.09$ & $>0.12$ & $>0.20$ & 0.27 & n.c. & n.c. \\
\hline 1,2,3,7,8 PCDD & 7 & 19 & 7 & 13 & 14 & $>0.73$ & $>1.41$ & $>0.89$ & 0.25 & 0.15 & 0.69 & 0.199 \\
\hline $1,2,3,4,7,8 \mathrm{HxCDD}$ & 6 & 14 & 4 & 4 & 8 & $>0.65$ & $>1.04$ & $>0.50$ & 0.08 & 0.03 & 0.00 & 1.000 \\
\hline 1,2,3,6,7,8 HxCDD & 4 & 15 & 4 & 4 & 11 & $>0.41$ & $>1.12$ & 0.10 & 0.05 & 0.07 & 0.15 & 0.812 \\
\hline 1,2,3,7,8,9 HxCDD & 6 & 12 & 4 & 4 & 7 & $>0.65$ & $>0.89$ & 0.03 & $>0.41$ & $>0.64$ & n.c. & n.c. \\
\hline 1,2,3,4,6,7,8 HpCDD & 39 & 29 & 13 & 21 & 25 & 0.03 & 0.22 & 0.02 & 0.01 & 0.01 & 0.30 & 0.623 \\
\hline 1,2,3,4,6,7,8,9 OCDD & 176 & 95 & 70 & 72 & 62 & 0.02 & 0.09 & 0.02 & 0.01 & 0.01 & -0.50 & 0.391 \\
\hline 2,3,7,8 TCDF & 108 & 22 & 43 & 181 & 487 & $>11.13$ & $>1.64$ & 0.63 & 0.94 & 1.35 & 0.82 & 0.089 \\
\hline 1,2,3,7,8 PCDF & 24 & 23 & 20 & 116 & 197 & 0.11 & 0.24 & 0.19 & 0.29 & 0.13 & 0.99 & $<0.001$ \\
\hline 2,3,4,7,8 PCDF & 29 & 18 & 15 & 78 & 155 & 0.29 & $>0.67$ & 0.43 & 0.40 & 0.46 & 0.99 & $<0.001$ \\
\hline 1,2,3,4,7,8 HxCDF & 34 & 26 & 15 & 108 & 354 & 0.07 & 0.27 & 0.10 & 0.16 & 0.10 & 0.90 & 0.037 \\
\hline 1,2,3,6,7,8 HxCDF & 16 & 19 & 8 & 46 & 117 & 0.10 & 0.32 & 0.10 & 0.14 & 0.08 & 0.90 & 0.037 \\
\hline 1,2,3,7,8,9 HxCDF & 9 & 19 & 4 & 10 & 19 & 0.01 & $>1.41$ & $>0.50$ & 0.00 & 0.09 & 0.00 & 1.000 \\
\hline 2,3,4,6,7,8 HxCDF & 17 & 24 & 10 & 38 & 72 & 0.32 & $>1.79$ & 0.15 & 0.11 & 0.08 & 0.60 & 0.285 \\
\hline $1,2,3,4,6,7,8 \mathrm{HpCDF}$ & 80 & 45 & 15 & 102 & 256 & 0.03 & 0.07 & 0.01 & 0.02 & 0.01 & 0.90 & 0.037 \\
\hline $1,2,3,4,7,8,9 \mathrm{HpCDF}$ & 18 & 22 & 8 & 24 & 80 & 0.05 & 0.16 & 0.05 & 0.07 & 0.02 & 0.90 & 0.037 \\
\hline $1,2,3,4,6,7,8,9$ OCDF & 539 & 150 & 26 & 78 & 239 & 0.10 & 0.11 & 0.01 & 0.02 & 0.00 & 0.30 & 0.624 \\
\hline$\Sigma$ PCDD & 241 & 186 & 104 & 122 & 134 & & & & & & & \\
\hline$\Sigma$ PCDF & 874 & 366 & 165 & 782 & 1,977 & & & & & & & \\
\hline$\Sigma \mathrm{PCDD} / \mathrm{F}$ & 1,115 & 552 & 269 & 904 & 2,111 & & & & & & & \\
\hline$\Sigma$ TE (WHO-TEQ) & 32 & 33 & 34 & 35 & 36 & & & & & & & \\
\hline
\end{tabular}

Concentration data are reported as real and normalized to organic carbon and lipid concentrations. For BSAFs calculation, data below detection limits were assigned a value equal to half detection limit. Results of correlation analysis performed on sediment and tissue dry weight data are also reported. Data highlighted in bold indicate significant correlations. n.c. = not calculated due to occurrence of too data under detection limit. 


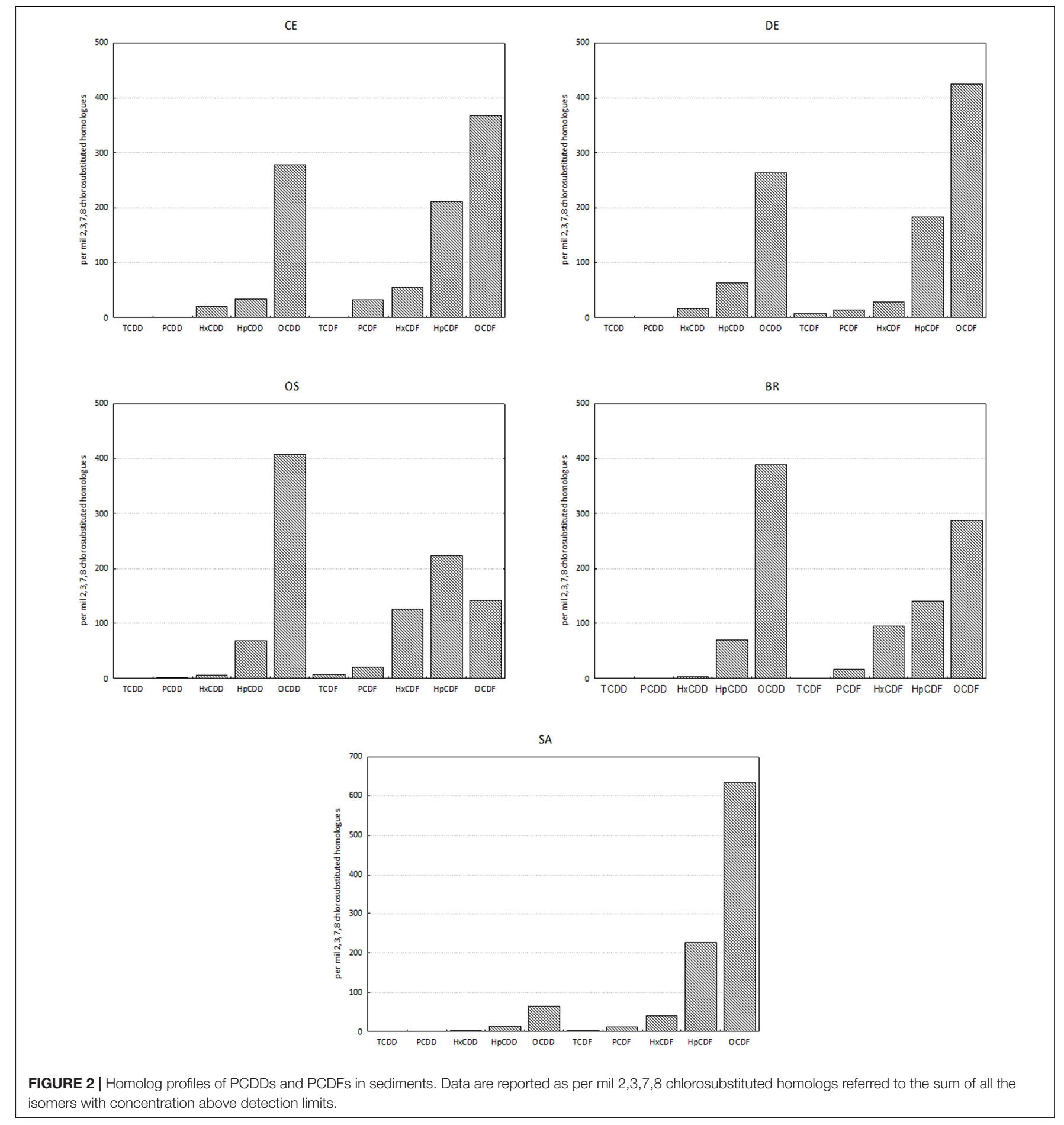

the industrial area (SA) and at the estuarine site OS located in the proximity of the illegal landfill and also receiving urban and industrial discharges.

A review of $\mathrm{PCDD} / \mathrm{F}$ concentration in the sediments of the Venice Lagoon reported a mean value of $14,000 \mathrm{pg} \mathrm{g}^{-1} \mathrm{dw}$ of $\Sigma \mathrm{PCDD} / \mathrm{F}$ for the industrial channels and $1,000 \mathrm{pg} \mathrm{g}^{-1}$ $\mathrm{dw}$ of $\Sigma \mathrm{PCDD} / \mathrm{F}$ for the inner lagoon (Guerzoni et al., 2007). These data are higher than those observed in the present study, both for the industrial district and the reference and estuarine samples; nevertheless, the comparison with literature data is often complicated by the different depth of the sediment core analyzed in the various studies. For the industrial district, many data refer to the first $2 \mathrm{~cm}$ of sediments, where concentrations in the range $67-13,642 \mathrm{pg} \mathrm{g}^{-1}$ for dioxins and 592-126,561 $\mathrm{pg} \mathrm{g}^{-1}$ for furans were reported (Bellucci et al., 2000; Frignani et al., 2001a); other projects investigated the vertical profile of PCDD/F 

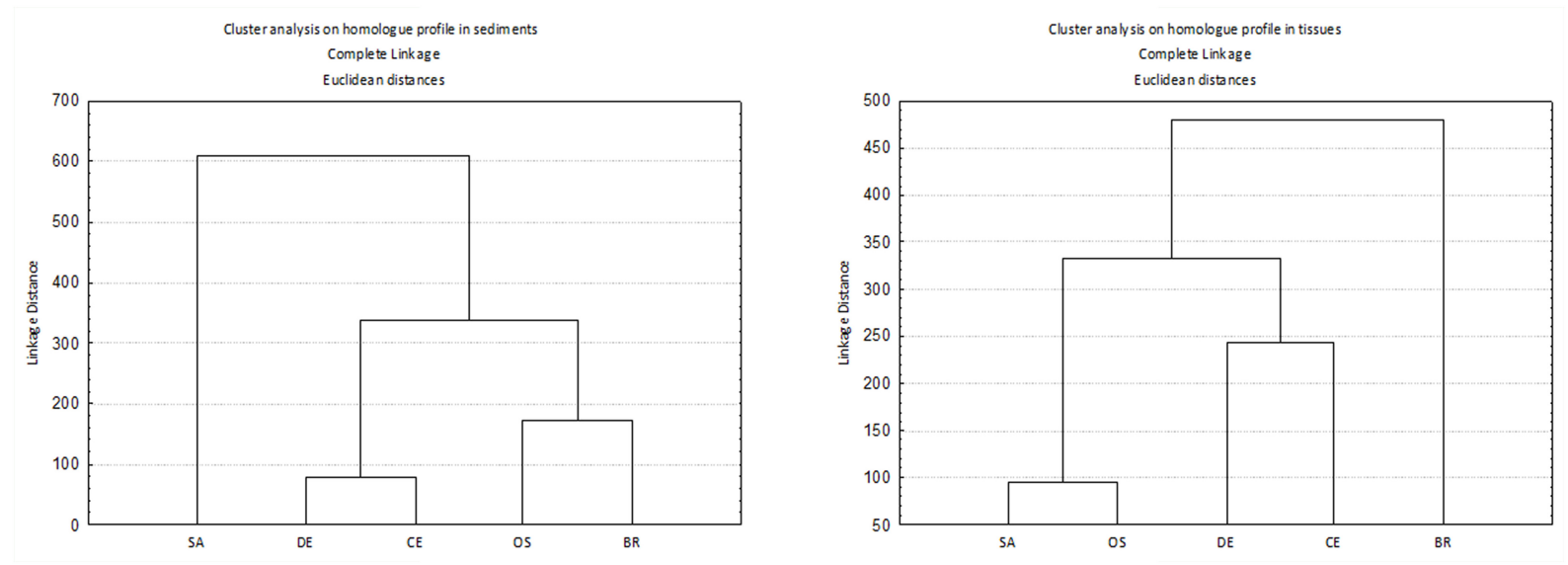

FIGURE 3 | Cluster analysis on homolog profile in sediments (left) and tissues (right). Before analysis, data were transformed to per mil 2,3,7,8 chlorosubstituted homologs referred to the sum of all the isomers with concentration above detection limits.

in industrial channels and reported concentrations up to 36,590 pg $\mathrm{g}^{-1} \mathrm{dw}$ for dioxins in the layer $35-38 \mathrm{~cm}$ depth and up to $19,241 \mathrm{pg} \mathrm{g}^{-1} \mathrm{dw}$ for furans in the layer $8-10 \mathrm{~cm}$ depth (Frignani et al., 2001a).

Later studies conducted by the Venice Water Authority investigated the top layer to a depth of $25 \mathrm{~cm}$ (MAG. ACQUEThetis, 2007) in the shallows of the inner lagoon facing the industrial district and reported concentrations in the range 13$8,312 \mathrm{pg} \mathrm{g}^{-1} \mathrm{dw}$ of $\Sigma \mathrm{PCDD} / \mathrm{F}$ and equivalent toxicity (WHOTEQ) up to $112 \mathrm{pg} \mathrm{g}^{-1} \mathrm{dw}$. These data are in agreement with the concentrations observed in the present study, both for the industrial district (SA, BR) as well as the estuarine sample OS. At this latter sample, the measured concentrations (1,402 pg $\mathrm{g}^{-1} \mathrm{dw}$ as $\Sigma \mathrm{PCDD} / \mathrm{F}$ ) were also higher than those reported in the literature (depth $0-20 \mathrm{~cm}$ ) for the inner lagoon shallows opposite to the estuary and in the proximity of the illegal landfill of Campalto (120 $\mathrm{pg} \mathrm{g}^{-1} \mathrm{dw}$ as $\Sigma$ PCDD/F) (Picone, 2006). These data suggest that the pollution of the area could be due mainly to the urban and industrial discharges upstream, rather than to leakages from the landfill.

Fewer data are available for the sites DE and CE. In surface sediment $(0-5 \mathrm{~cm})$ collected in the estuarine site DE, Jimenez et al. (1998) measured a total $\Sigma \mathrm{PCDD} / \mathrm{F}$ concentration of $79 \mathrm{pg} \mathrm{g}^{-1} \mathrm{dw}$.

The profiles of the homologs and the cluster analysis evidenced three distinct patterns of $\mathrm{PCDD} / \mathrm{F}$ at the five study sites, that may be related to different sources of contamination. In the sediment of the industrial area Bellucci et al. (2000) already identified three distinct type of homolog profiles that fit with the main local sources: (type 1) profile dominated almost entirely by OCDD, produced by combustion processes, untreated domestic sewage, urban wastes and boat engine exhausts; (type 2) profile with the dominance of OCDF (90\%) and OCDD (10\%) that could be ascribed both to the stripping of vinyl chloride monomer (Stringer et al., 1995) and to the accumulation of atmospheric contaminants caused by both the runoff from the industrial district and the wastes of a factory for the production of liquid gases (Frignani et al., 2001a); and (type 3) profile containing mainly furans, with a prevailing component of OCDF, probably due to the production of metals, coke and related chemicals in the industrial district.

Nevertheless, in the present study only the sample collected from Canale Industriale Sud (SA), showed a profile that could be categorized into one of the three types outlined by Bellucci et al. (2000) since the homologs provided a specific pattern of furans with a dominance of OCDF, attributable to industrial production of coke, metals and related manufactories (type 3 ), whilst contribution of dioxins in negligible. In the remaining four samples, the profiles did not allow for the identification of a prevailing source, but indicate the co-occurrence of multiple sources of contamination. Samples CE and DE were characterized by a pattern of PCDD/F, consistent with atmospheric deposition from industrial sources. However, their profiles showed also a noteworthy contribution of OCDD, suggesting a not-negligible contribution of combustion processes unrelated to industrial pollution and boat traffic. In contrast, in samples OS and BR the dominance of OCDD over OCDF and HpCDF suggested a major contribution of deposition due to combustion combined with untreated domestic sewage over the deposition of furans from industrial sources.

\section{PCDD/F in Tissues}

In general, very few data are available in the literature concerning the field bioaccumulation of PCDD/F in polychaetes, although ragworms and lugworms are widely used as a bioindicator for biomarker and bioaccumulation studies (Ruus et al., 2005; Durou et al., 2007a,b) and are a key component of the coastal and estuarine food webs. Studies on $H$. diversicolor were performed by Nunes et al. (2011), that reported a concentration in tissues of $1.38 \mathrm{pg} \mathrm{g} \mathrm{g}^{-1} \mathrm{ww}$ of $\Sigma$ PCDD/F (81.16 $\mathrm{pg} \mathrm{g}^{-1}$ lipid) for the Mondego estuary, Portugal. These data were lower than the concentration normalized to lipids observed both in the industrial district and in the estuarine sites of the Venice Lagoon 

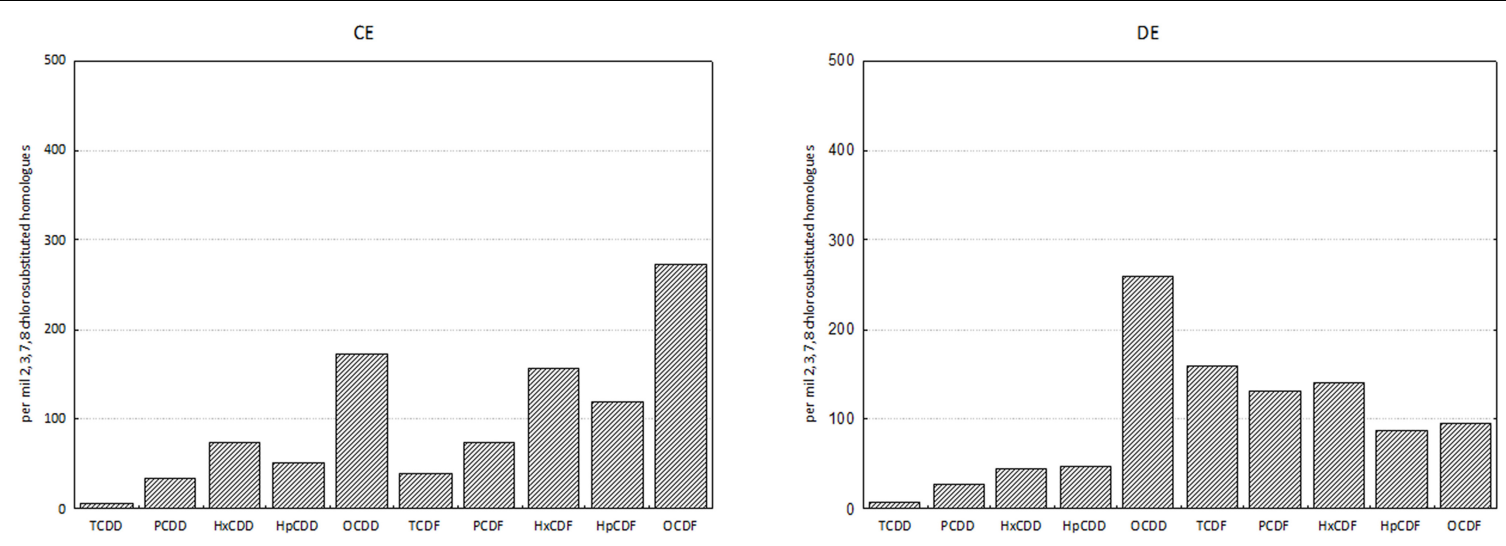

oS
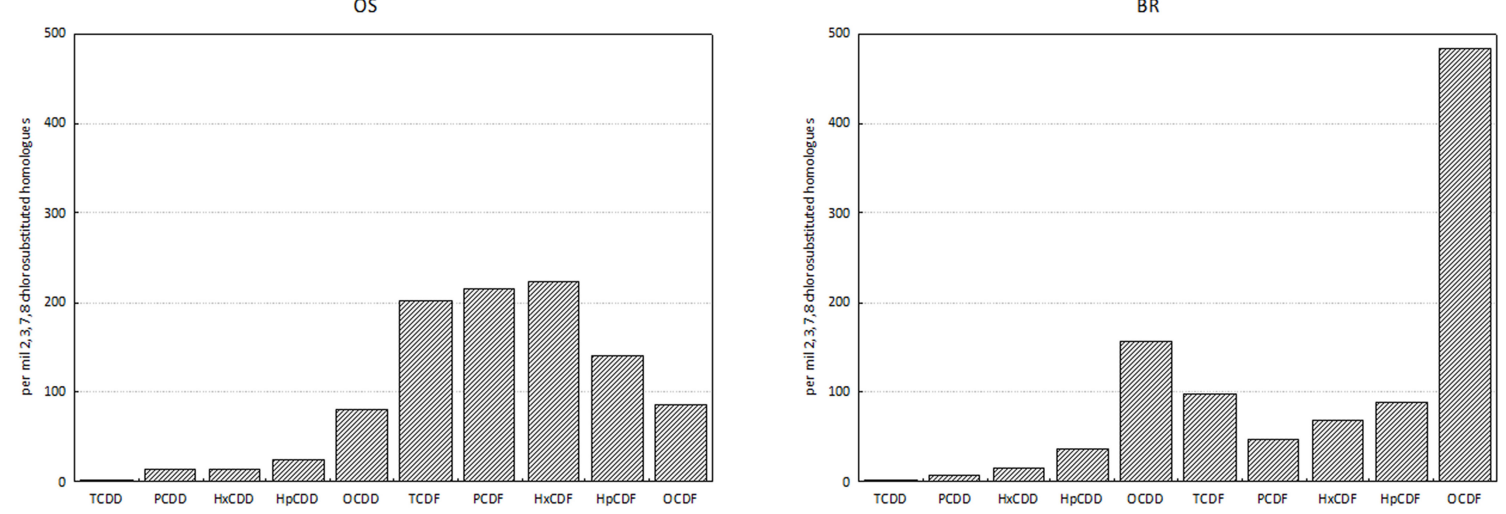

SA

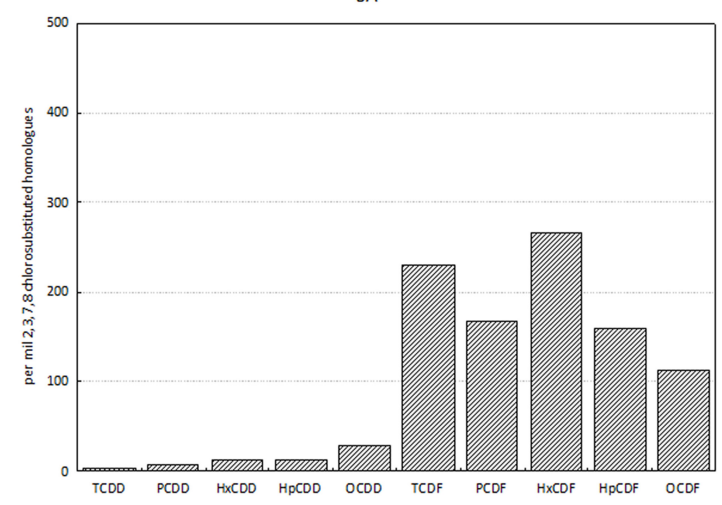

FIGURE 4 | Homolog profiles of PCDDs and PCDFs in tissues of $H$. diversicolor. Data are reported as per mil 2,3,7,8 chlorosubstituted homologs referred to the sum of all the isomers with concentration above detection limits.

in the present study (269-2,111 $\mathrm{pg} \mathrm{g}^{-1}$ lipid), and may be related to the different levels and kind of pollution sources affecting the two estuaries.

In the Venice Lagoon the bioaccumulation of PCDD/F from the sediments has been most often assessed by measuring tissue concentration in clams and fishes, and never in polychaetes. Various studies have focused on the concentrations of $\mathrm{PCDD} / \mathrm{F}$ in the Manila clam (Ruditapes philippinarum) collected both in the industrial district and in the inner lagoon: Sfriso et al. (2014) measured concentrations in the range of $40-110 \mathrm{pg} \mathrm{g}^{-1} \mathrm{dw}$ for the inner lagoon, corresponding to an equivalent toxicity (WHO-TEQ) of 0.49-1.46 $\mathrm{pg} \mathrm{g}^{-1} \mathrm{ww}$; Raccanelli et al. $(2004,2008)$ reported for the industrial area an equivalent toxicity of 2-9 $\mathrm{pg} \mathrm{g}^{-1}$ ww; MAG. ACQUE-Thetis (2006) reported concentrations in the range $40-717 \mathrm{pg} \mathrm{g}^{-1}$ lipid and $9-58 \mathrm{pg} \mathrm{g}^{-1}$ lipid for industrial area and inner lagoon, respectively. In this latter study also the levels of $\mathrm{PCDD} / \mathrm{F}$ in the muscle of the grass goby Zosterisessor ophiocephalus were 


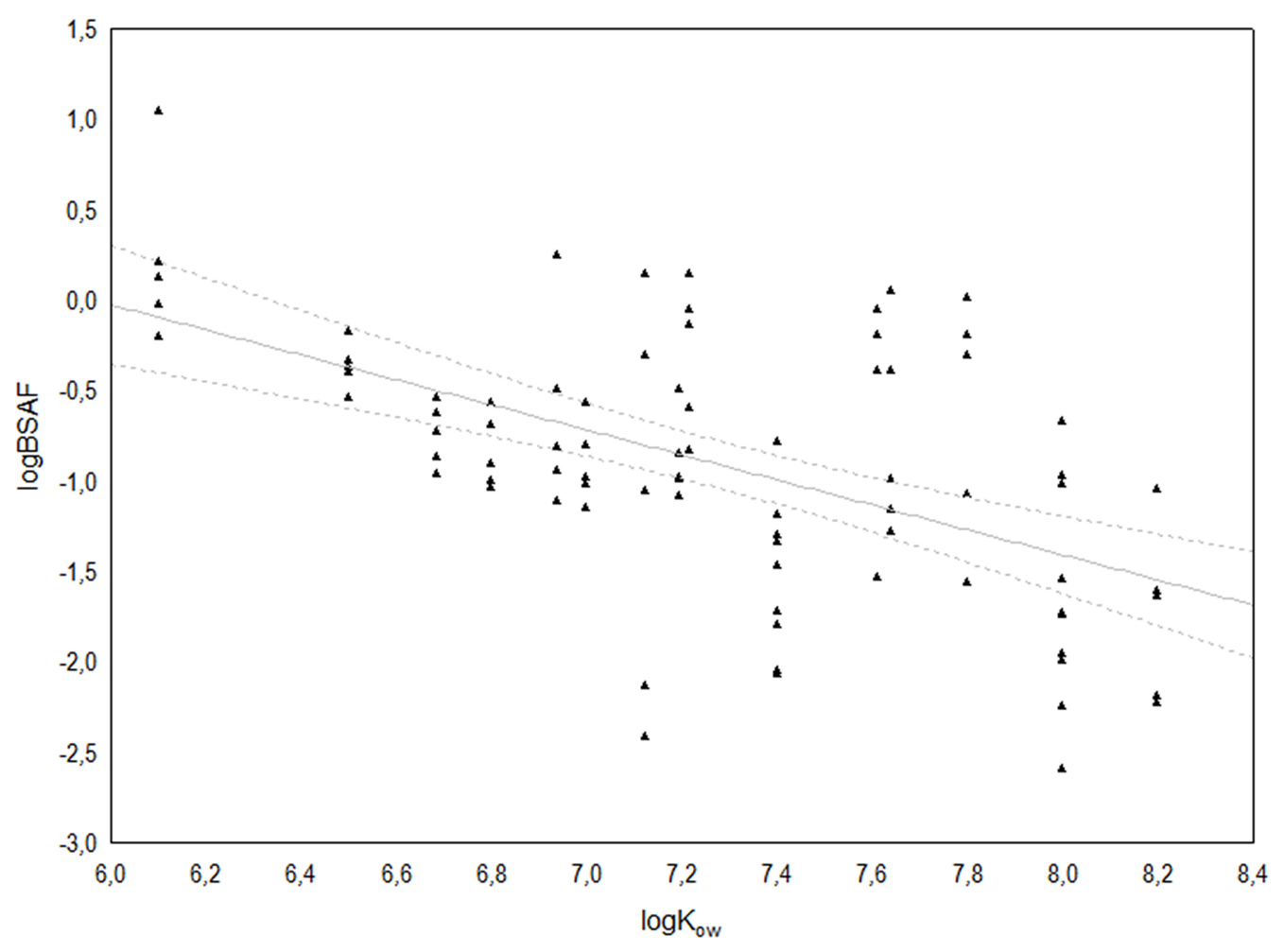

FIGURE 5 | Relationship between log Kow and log BSAF for the 17 congeners of 2,3,7,8 chlorosubstituted dioxins and furans. The solid line represents the linear regression $\log (\mathrm{BSAF})=4.12-0.69 \log \left(\mathrm{K}_{\mathrm{OW}}\right)\left(r^{2}=0.289\right)$, whilst broken lines indicate the $95 \%$ confidence interval.

measured, ranging between 14 and $435 \mathrm{pg} \mathrm{g}^{-1}$ lipid for the inner lagoon and $78-640 \mathrm{pg} \mathrm{g}^{-1}$ lipid for the industrial area (MAG. ACQUE-Thetis, 2006). Tissue concentrations in gobies are in agreement with the observed concentrations measured in polychaete tissues in the present study. Other authors also reported data for the thicklip gray mullet Chelon labrosus (1.6-2.6 $\mathrm{pg} \mathrm{g}^{-1}$ ww of $\Sigma$ PCDD/F) and the crab Carcinus aestuarii, both in the industrial district $\left(36 \mathrm{pg} \mathrm{g}^{-1} \mathrm{ww}\right.$ of $\Sigma$ $\mathrm{PCDD} / \mathrm{F})$ and in the inner lagoon (1.5-5 $\mathrm{pg} \mathrm{g}^{-1} \mathrm{ww}$ of $\Sigma$ PCDD/F) (Jimenez et al., 1998; MAG. ACQUE, 1999).

Homolog profiles indicated that the polychaetes accumulated OCDD preferentially as concern dioxins, whilst two different patterns are evident for furans: at sites $\mathrm{CE}$ and $\mathrm{BR}$ the dominant congener was the more chlorinated OCDF, whilst in samples $\mathrm{SA}$, OS and also $\mathrm{DE}$ there was a relevant contribution of the less chlorinated congeners. In particular, there was a notable contribution provided by $2,3,7,8-\mathrm{TCDF}$, a typical marker of pollution due to chloralkali plants (Jimenez et al., 1998).

\section{Comparison Between Sediments and Tissues}

Sediment concentrations were higher than tissue concentrations for all the analyzed $\mathrm{PCDD} / \mathrm{F}$, apart from the less chlorinated furan 2,3,7,8-TCDF and 2,3,4,7,8$\mathrm{PeCDF}$, whose concentrations were higher in the tissues of
$H$. diversicolor than in the sediments at the same stations. The differences were up to one order of magnitude for the hepta- and octa-chlorinated congeners, especially at sites $\mathrm{DE}$, OS and SA, whilst the trend was less evident for the hexa-chlorinated congeners.

Homolog profiles and Spearman's correlation showed a generally low association between congener concentrations in sediment and polychaete tissues, resulting in large variability among the corresponding BSAF values. On the other hand, the significant linear relation observed between $\operatorname{logBSAF}$ and $\log \mathrm{K}_{\mathrm{OW}}$, despite having a low coefficient of determination $\left(r^{2}=0.289\right)$, outlined polychaete's tendency to take up preferentially the less chlorinated and less lipophilic congeners, characterized by lower $\log \mathrm{K}_{\mathrm{OW}}$, as also observed by Kono et al. (2010) in a laboratory study aiming to model the dioxin transfer from sediments to Perinereis nuntia. These authors also evidenced that bioaccumulation of $\mathrm{PCDD} / \mathrm{F}$ in polychaetes follow similar characteristics to those observed in fishes (Sijm et al., 1993).

The congeners 2,3,7,8-TCDD and 2,3,7,8-TCDF are characterized by high bioaccumulation and low elimination; thus their BSAF tends to be higher than those of the more chlorinated congeners (Sijm et al., 1993; Kono et al., 2010). In the case of $H$. diversicolor this is evident for 2,3,7,8-TCDF, whose accumulation factors were the highest in all the analyzed sample (except CE) despite the low sediment concentrations; 


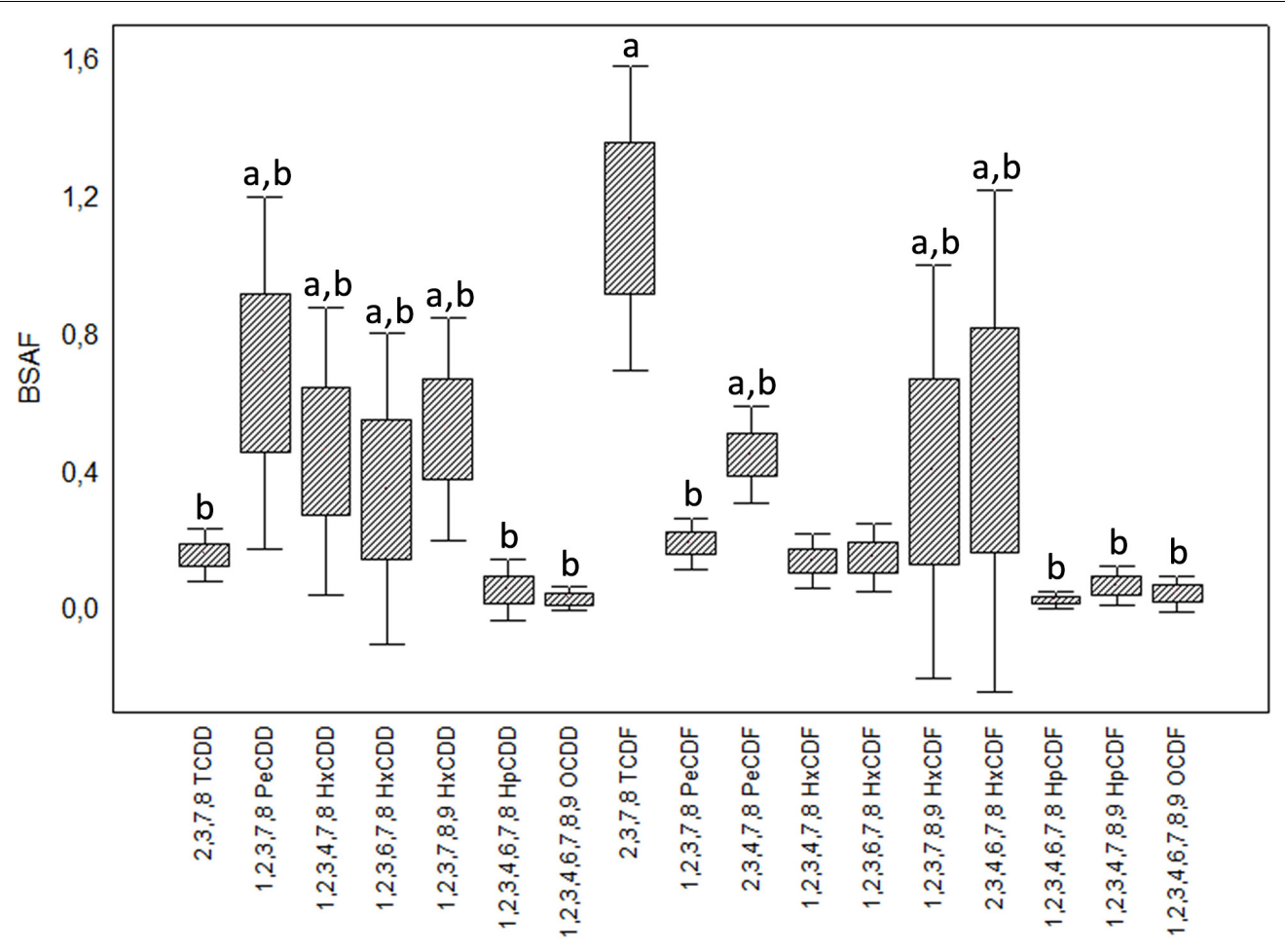

FIGURE 6 | Biota-to-Sediment Accumulation Factors (BSAF) calculated for the 17 congeners of 2,3,7,8 chlorinated dioxins and furans. Boxes indicate mean \pm standard error, whiskers mean \pm standard deviation. Letter "a" identifies congeners with mean BSAF statistically different from 2,3,7,8-TCDF (after Kruskal-Wallis ANOVA and multiple comparison test).

for 2,3,7,8-TCDD this trend is not tangible, probably due to the sediment concentrations below detection limits that impeded any further analysis. Preferential accumulation of tetrachlorinated congeners has also been observed by Pruell et al. (2000) for the Nereididae Alitta virens following 70-d laboratory exposure to contaminated sediments: in this case, polychaetes accumulated only 2,3,7,8-TCDD and 2,3,7,8-TCDF, although the sediments were characterized by a range of $\mathrm{PCDD} / \mathrm{F}$ and also high concentrations of highly chlorinated congeners.

On the other hand, 1,2,3,4,6,7,8-HpCDD, HpCDFs, $1,2,3,4,6,7,8,9-\mathrm{OCDD}$ and $1,2,3,4,6,7,8,9-\mathrm{OCDF}$ are congeners characterized by low bioaccumulation, as applies to all the 1,4-substituted and/or 6,9-substituted PCDD/F (Sijm et al., 1993; Kono et al., 2010). Both low bioavailability and elimination may contribute to the low accumulation (and also BSAF) of highly chlorinated PCDD/F. Lipophilicity is a major contributor for determining the bioavailability of sediment-bound PCDD/F, as confirmed by the negative relationship of $\mathrm{BSAF}$ versus $\mathrm{K}_{\mathrm{OW}}$ in $H$. diversicolor (this study) and $P$. nuntia. However, contaminant molecular size and conformation (specifically planarity/nonplanarity), sediment characteristics and feeding habits may also play a significant role, as observed in oligochaetes (Lyytikäinen et al., 2003). Elimination of highly chlorinated PCDD/F in caddisfly larvae and oligochaetes fits a biphasic model (Loonen et al., 1997; Pastershank et al., 1999). A first, rapid depuration phase was attributed to the elimination of the gut content, facilitated by a low assimilation efficiency for highly chlorinated compounds, whilst the slower phase of the depuration was attributed to elimination from other body compartments. The elimination process in polychaetes has not yet been elucidated, but a significant correlation between the elimination constant $\left(\mathrm{k}_{2}\right)$ and $\log \mathrm{K}_{\mathrm{OW}}$ has been observed by Kono et al. (2010), supporting the hypothesis that more chlorinated and hydrophobic congeners do not bioaccumulate since they are quickly eliminated. In fish and oligochaetes the more rapid elimination of super-hydrophobic organics as OCDD compared to lower chlorinated PCBs, TCDD and TCDF also observed in human blood (Flesch-Janys, 1996) - also suggests that OCDD in invertebrates is mainly associated with fast-clearing compartments as cell membranes or blood serum (Kono et al., 2010).

The BSAFs for PCDD/F observed in the present study with $H$. diversicolor (0.02-1.41 for dioxins; 0.01 - 11.13 for furans) are at least one order of magnitude higher than those measured in $P$. nuntia (0.00036-0.22 for dioxins and 0.0002-0.36 for furans) (Kono et al., 2010); moreover, the data are in agreement with the BSAFs reported for other polychaetes such as Nephtys sp. (McFarland et al., 1994) and A. virens (Pruell et al., 1993, 2000; Schrock et al., 1997). In all cases, the BSAF obtained with $H$. diversicolor for 2,3,7,8TCDF is higher than those reported for other polychaete species, suggesting a specific ability of $H$. diversicolor to 
accumulate this congener. Since bioavailability is a crucial factor driving bioaccumulation, and digestive fluids are the primary factors driving solubilization of organic contaminants in polychaetes (Voparil and Mayer, 2000; Ahrens et al., 2001), differences in BSAFs for 2,3,7,8-TCDF among $H$. diversicolor and other polychaete species may be due to differences in gut digestive chemistry. Concentrations and properties of digestive fluids vary broadly among species and it may affect the assimilation efficiency for some substances (Ahrens et al., 2001; Mayer et al., 2001). When compared to other invertebrates, the BSAFs calculated for $H$. diversicolor are in agreement with data reported for the freshwater oligochaete Lumbriculus variegatus (0.024-2.54), the crustaceans Palaemonetes pugio and Callinectes sapidus (0.089-0.73 in the hepatopancreas), the bivalves Macoma nasuta and Corbicula japonica (0.0040.22 for PCDD/F) (Pruell et al., 1993; Schell et al., 1993; Kang et al., 2002; Pickard and Clarke, 2008; Iannuzzi et al., 2011). Also in this case, similarities in BSAFs may be due to comparable efficiency of the digestive fluids in the solubilization of the contaminants, as shown by Mayer et al. (2001) for benzo[a]pyrene.

Sediment Accumulation Factor data suggest that $H$. diversicolor may accumulate PCDD/F significantly from the sediments and may serve as an indicator for the bioavailability of dioxins and furans from sediments to the polychaete community, especially as concerns the less chlorinated 2,3,7,8-TCDF, 2,3,4,7,8-PeCDF and 2,3,4,7,8-PeCDD. Nevertheless, the BSAFs for $\mathrm{PCDD} / \mathrm{F}$ in polychaetes are generally low $(\mathrm{BSAF}<1$ or less) when compared to the BSAFs measured for other organochlorine contaminants (i.e., $\mathrm{PCBs}$ and organochlorine pesticides) in a number of species including $A$. virens, $N$. incisa, Glycera sp., Perinereis nuntia and also $H$. diversicolor (Lake et al., 1990; Brannon et al., 1993; Volpi Ghirardini et al., 2004; Kono et al., 2010; Nesto et al., 2010); this trend was also observed in fishes where the apparent lower bioaccumulation of $\mathrm{PCDD} / \mathrm{F}$ was attributed to lower solubility in the lipids, reduced membrane transport and also biotransformation mediated by cytochrome $\mathrm{P} 450$ monooxygenase isozymes (Opperhuizen and Sijm, 1990; Sijm et al., 1993; van der Oost et al., 2003). Biotransformation of $\mathrm{PCDD} / \mathrm{F}$ in polychaetes has been rarely studied, and no data are available concerning the possible mechanisms involved. Nevertheless, since cytochrome P450 isozymes are active also in polychaetes (Zheng et al., 2013), it cannot be excluded that the lower bioaccumulation of $\mathrm{PCDD} / \mathrm{F}$ in ragworms could be due to the same causes already identified for fishes. Further studies are needed, however, to elucidate these possible mechanisms of biotransformation and elimination.

\section{CONCLUSION}

Total PCDD/F concentrations in sediments in Venice Lagoon showed a clear pollution gradient along the investigated sites, with higher levels of contamination in the samples collected in the industrial district (SA) and in the estuarine site receiving urban and industrial discharges from the area of Mestre and the illegal landfill of San Giuliano. Distinctly different homolog profiles discriminated between sites influenced by heterogeneous pollution sources (BR, OS, DE and CE) and the industrial site (SA), where a specific pattern of furans with a dominance of OCDF attributable to industrial production of coke, metals and related manufactories was observed.

In the ragworm tissues, the concentration pattern of the congeners is different from those observed in the sediments, especially with regard to furans: in sample CE and BR the polychaetes accumulated mostly $1,2,3,4,6,7,8,9$ OCDF whilst in samples SA, OS and DE the major contribution was due to the less substituted congeners and principally 2,3,7,8-TCDF, recognized as a marker of possible contamination deriving from chloralkali industrial plants.

In general, $H$. diversicolor was a good indicator for assessing the transfer of PCDD/F from sediment to biota, but accumulated more efficiently the less chlorinated congeners with lower $\log K_{\mathrm{OW}}$ resulting in a negative correlation between BSAF and $\mathrm{K}_{\mathrm{Ow}}$, after logarithmic transformation.

Despite $H$. diversicolor's ability to accumulate 2,3,7,8-TCDD, 2,3,7,8-TCDF and 2,3,4,7,8-PeCDF, the BSAFs calculated for the $\mathrm{PCDD} / \mathrm{F}$ are low as compared with those reported in the literature for other organochlorine compounds (i.e., PCBs and organochlorine pesticides) in a number of species including A. virens, N. incisa, Glycera sp., Perinereis nuntia and also $H$. diversicolor. Lower $\mathrm{BSAFs}$ for $\mathrm{PCDD} / \mathrm{F}$ may be due to different uptake kinetics, or the presence in polychaetes of a more efficient elimination pathway for $\mathrm{PCDD} / \mathrm{F}$ than for PCBs or pesticides, possibly involving also cyt-P450-mediated biotransformations; further research is needed to identify both biotransformation and elimination processes driving accumulation in polychaetes. Due to the paucity of information on this species, this research not only represents a baseline but also an invitation for further ecotoxicological studies on $H$. diversicolor.

\section{DATA AVAILABILITY STATEMENT}

All datasets generated for this study are included in the article/supplementary material.

\section{AUTHOR CONTRIBUTIONS}

MP developed the manuscript concept, wrote the manuscript, and took care of the statistical analyses. ED contributed to the development of the study design, supported sampling, took care of data analysis, and commented on the manuscript. DT participated in the development of study design, supported sampling and handling, and commented on the manuscript. IG supported the analysis and commented on the manuscript. AV developed the study design, participated in the manuscript concept development, supported writing and analysis. All authors contributed to the article and approved the submitted version. 


\section{FUNDING}

This study was financially supported by the project ORIZZONTE 2023, funded by the Venice Water Authority through its concessionaire Consorzio Venezia Nuova.

\section{REFERENCES}

Ahrens, M., Hertz, J., Lamoureux, E., Lopez, G., McElroy, A., and Brownawell, B. (2001). The role of digestive surfactants in determining bioavailability of sediment-bound hydrophobic organic contaminants to 2 deposit-feeding polychaetes. Mar. Ecol. Prog. Ser. 212, 145-157. doi: 10.3354/meps212145

Amiard-Triquet, C., Mouneyrac, C., and Berthet, B. (2013). "Polychaetes in Ecotoxicology," in Encyclopedia of Aquatic Ecotoxicology, eds J.-F. Férard and C. Blaise (Dordrecht: Springer Science+Business Media), 893-908. doi: 10.1007/ 978-94-007-5704-2_82

Armitage, J. M., McLachlan, M. S., Wiberg, K., and Jonsson, P. (2009). A model assessment of polychlorinated dibenzo-p-dioxin and dibenzofuran sources and fate in the Baltic Sea. Sci. Total Environ. 407, 3784-3792. doi: 10.1016/J. SCITOTENV.2009.03.001

ASTM (2014). Standard Guide for Collection, Storage, Characterization, and Manipulation of Sediments for Toxicological Testing and for Selection of Samplers Used to Collect Benthic Invertebrates (E1391 - 03). West Conshohocken, PA: American Society for Testing Materials.

Bellucci, L. G., Frignani, M., Raccanelli, S., and Carraro, C. (2000). Polychlorinated dibenzo-p-dioxins and dibenzofurans in surficial sediments of the venice lagoon (Italy). Mar. Pollut. Bull. 40, 65-76. doi: 10.1016/S0025-326X(99) 00171-X

Bellucci, L. G., Giuliani, S., Mugnai, C., Frignani, M., Paolucci, D., Albertazzi, S., et al. (2009). Anthropogenic metal delivery in sediments of porto marghera and venice lagoon (Italy). Soil Sediment Contam. An Int. J. 19, 42-57. doi: $10.1080 / 15320380903390562$

Bernstein, A. G., and Montobbio, L. (2011). La gestione dei sedimenti in laguna di Venezia. Sintesi dei principali risultati acquisiti da studi e indagini di base. Quad. Trimest. del Consorzio Venezia Nuova 1.11, 41-59.

Berthet, B., Mouneyrac, C., Amiard, J. C., Amiard-Triquet, C., Berthelot, Y., Le Hen, A., et al. (2003). Accumulation and soluble binding of cadmium, copper, and zinc in the polychaete hediste diversicolor from coastal sites with different trace metal bioavailabilities. Arch. Environ. Contam. Toxicol. 45, 468-478. doi: 10.1007/s00244-003-0135-0

Bettiol, C., Collavini, F., Guerzoni, S., Molinaroli, E., Rossini, P., Zaggia, L., et al. (2005). Atmospheric and riverine inputs of metals, nutrients and persistent organic pollutants into the lagoon of Venice. Hydrobiologia 550, 151-165. doi: 10.1007/s10750-005-4372-2

Brannon, J. M., Price, C. B., Reilly, F. J., Pennington, J. C., and Mcfarland, V. A. (1993). Effects of sediment organic carbon on distribution of radiolabeled fluoranthene and PCBs among sediment, interstitial water, and biota. Bull. Environ. Contam. Toxicol. 51, 873-880. doi: 10.1007/bf00198284

Burkhard, L. (2009). Estimation of Biota Sediment Accumulation Factor (BSAF) From Paired Observations of Chemical Concentrations in Biota and Sediment. Cincinnati, OH: U.S. Environmental Protection Agency.

Chen, J., Quan, X., Yazhi, Z., Yan, Y., and Yang, F. (2001). Quantitative structureproperty relationship studies on n-octanol/water partitioning coefficients of PCDD/Fs. Chemosphere 44, 1369-1374. doi: 10.1016/S0045-6535(00)00347-7

Cornelissen, G., Breedveld, G. D., Naes, K., Oen, A. M. P., and Ruus, A. (2006). Bioaccumulation of native polycyclic aromatic hydrocarbons from sediment by a polychaete and a gastropod: freely dissolved concentrations and activated carbon amendment. Environ. Toxicol. Chem. 25, 2349-2355.

Critto, A., Carlon, C., and Marcomini, A. (2003). Characterization of contaminated soil and groundwater surrounding an illegal landfill (S. Giuliano, Venice, Italy) by principal component analysis and kriging. Environ. Pollut. 122, 235-244. doi: 10.1016/S0269-7491(02)00296-8

Dean, H. K. (2008). The use of polychaetes (Annelida) as indicator species of marine pollution: a review. Rev. Biol. Trop. 56, 11-38.

Durou, C., Poirier, L., Amiard, J. C., Budzinski, H., Gnassia-Barelli, M., Lemenach, K., et al. (2007a). Biomonitoring in a clean and a multi-contaminated estuary

\section{ACKNOWLEDGMENTS}

The authors are very grateful to Michele Cornello and Alessandra Arizzi Novelli for helping with sampling and handling of sediment and polychaetes.

based on biomarkers and chemical analyses in the endobenthic worm Nereis diversicolor. Environ. Pollut. 148, 445-458. doi: 10.1016/j.envpol.2006.12.022

Durou, C., Smith, B. D., Roméo, M., Rainbow, P. S., Mouneyrac, C., Mouloud, M., et al. (2007b). From biomarkers to population responses in Nereis diversicolor: assessment of stress in estuarine ecosystems. Ecotoxicol. Environ. Saf. 66, 402-411. doi: 10.1016/j.ecoenv.2006.02.016

Fattore, E., Benfenati, E., Mariani, G., Fanelli, R., and Evers, E. H. G. (1997). Patterns and sources of polychlorinated dibenzo-p-dioxins and dibenzofurans in sediments from the venice lagoon, Italy. Environ. Sci. Technol. 31, 1777-1784. doi: 10.1021/ES9608860

Flesch-Janys, D. (1996). Elimination of polychlorinated dibenzo-p-dioxins and dibenzofurans in occupationally exposed persons. J. Toxicol. Environ. Health 47, 363-378. doi: 10.1080/009841096161708

Frangipane, G., Volpi Ghirardini, A., Collavini, F., Zaggia, L., Pesce, A., and Tagliapietra, D. (2005). Heavy metals in Hediste diversicolor (polychaeta: nereididae) and salt marsh sediments from the lagoon of Venice (Italy). Chem. Ecol. 21, 441-454. doi: 10.1080/02757540500438649

Frignani, M., Bellucci, L. G., Carraro, C., and Favotto, M. (2001a). Accumulation of polychlorinated dibenzo-p-dioxins and dibenzofurans in sediments of the venice lagoon and the industrial area of porto marghera. Mar. Pollut. Bull. 42, 544-553. doi: 10.1016/S0025-326X(00)00197-1

Frignani, M., Bellucci, L. G., Carraro, C., and Raccanelli, S. (2001b). Polychlorinated biphenyls in sediments of the Venice Lagoon. Chemosphere 43, 567-575. doi: 10.1016/S0045-6535(00)00408-2

Gambaro, A., Radaelli, M., Piazza, R., Stortini, A. M., Contini, D., Belosi, F., et al. (2009). Organic micropollutants in wet and dry depositions in the Venice Lagoon. Chemosphere 76, 1017-1022. doi: 10.1016/J.CHEMOSPHERE.2009.04. 063

Guerzoni, S., Rossini, P., Molinaroli, E., Rampazzo, G., and Raccanelli, S. (2004). Measurement of atmospheric deposition of polychlorinated dibenzo-p-dioxins and dibenzofurans in the Lagoon of Venice, Italy. Chemosphere 54, 1309-1317. doi: 10.1016/S0045-6535(03)00249-2

Guerzoni, S., Rossini, P., Sarretta, A., Raccanelli, S., Ferrari, G., and Molinaroli, E. (2007). POPs in the Lagoon of Venice: budgets and pathways. Chemosphere 67, 1776-1785. doi: 10.1016/j.chemosphere.2006.05.085

Gunnarsson, J. S., Hollertz, K., and Rosenberg, R. (1999). Effects of organic enrichment and burrowing activity of the polychaete Neries diversicolor on the fate of tetrachlorobiphenyl in marine sediments. Environ. Toxicol. Chem. 18, 1149-1156. doi: 10.1002/etc.5620180612

Iannuzzi, J., Butcher, M., and Iannuzzi, T. (2011). Evaluation of potential relationships between chemical contaminants in sediments and aquatic organisms from the lower Passaic River, New Jersey, USA. Environ. Toxicol. Chem. 30, 1721-1728. doi: 10.1002/etc.550

Jimenez, B., Hernandez, L. M., Gonzalez, M. J., Eljarrat, E., Rivera, J., and Fossi, M. C. (1998). Congener specific analysis of polychlorinated dibenzo-p-dioxins and dibenzofurans in crabs and sediments from the venice and orbetello lagoons, Italy. Environ. Sci. Technol. 32, 3853-3861. doi: 10.1021/ES9801994

Jørgensen, A., Giessing, A. M. B., Rasmussen, L. J., and Andersen, O. (2008). Biotransformation of polycyclic aromatic hydrocarbons in marine polychaetes. Mar. Environ. Res. 65, 171-186. doi: 10.1016/J.MARENVRES.2007.10.001

Kang, Y.-S., Yamamuro, M., Masunaga, S., and Nakanishi, J. (2002). Specific biomagnification of polychlorinated dibenzo-p-dioxins and dibenzofurans in tufted ducks (Aythya fuligula), common cormorants (Phalacrocorax carbo) and their prey from Lake Shinji, Japan. Chemosphere 46, 1373-1382. doi: 10.1016/ S0045-6535(01)00259-4

Khairy, M., Barrett, K., and Lohmann, R. (2016). Changing sources of polychlorinated dibenzo- $\mathrm{p}$-dioxins and furans in sediments and ecological risk for nekton in the lower Passaic River and Newark Bay, New Jersey, USA. Environ. Toxicol. Chem. 35, 550-562. doi: 10.1002/etc.3223

Kjerfve, B. (1994). Coastal Lagoon Processes. Amsterdam: Elsevier. 
Kono, K., Tanaka, H., and Koyama, J. (2010). Dioxin transfer from sediment to the infaunal surface deposit-feeding polychaete Perinereis nuntia in a laboratoryrearing experiment. Environ. Toxicol. Chem. 29, 1512-1519. doi: 10.1002/etc. 177

Lake, J. L., Rubinstein, N. I., Lee, H., Lake, C. A., Heltshe, J., and Pavignano, S. (1990). Equilibrium partitioning and bioaccumulation of sediment-associated contaminants by infaunal organisms. Environ. Toxicol. Chem. 9, 1095-1106. doi: $10.1002 /$ etc.5620090816

Langston, W. J., O’Hara, S., Pope, N. D., Davey, M., Shortridge, E., Imamura, M., et al. (2012). Bioaccumulation surveillance in milford haven waterway. Environ. Monit. Assess. 184, 289-311. doi: 10.1007/s10661-011-1968-z

Lobel, P. B., Belkhode, S. P., Jackson, S. E., and Longerich, H. P. (1991). Sediment in the intestinal tract: a potentially serious source of error in aquatic biological monitoring programs. Mar. Environ. Res. 31, 163-174. doi: 10.1016/01411136(91)90009-W

Loonen, H., Muir, D. C. G., Parsons, J. R., and Govers, H. A. J. (1997). Bioaccumulation of polychlorinated dibenzo- $\mathrm{p}$-dioxins in sediment by oligochaetes: influence of exposure pathway and contact time. Environ. Toxicol. Chem. 16, 1518-1525. doi: 10.1002/etc.5620160728

Lyytikäinen, M., Hirva, P., Minkkinen, P., Hämäläinen, H., Rantalainen, A.-L., Mikkelson, P., et al. (2003). Bioavailability of sediment-associated PCDD/Fs and PCDEs: relative importance of contaminant and sediment characteristics and biological factors. Environ. Sci. Technol. 37, 3926-3934. doi: 10.1021/ ES034151O

MAG. ACQUE (1999). Mappatura dellinquinamento Dei Fondali Lagunari. Studi ed indagini. Rapporto finale. Venice: MAG-ACQUE.

MAG. ACQUE-Thetis (2006). Studio ICSEL. Rapporto finale sull'attività svolta nel triennio 2003 - 2006. Venice: MAG-ACQUE.

MAG. ACQUE-Thetis (2007). Indagini e Monitoraggi Nelle Aree Lagunari Tra Venezia e Porto Marghera. Studio MAPVE1 - OP/399. I^ fase. Attività A Risultati Della Caratterizzazione Dello Stato Delle Matrici Ambientali. Venice: MAG-ACQUE.

MAG. ACQUE-Uta (2011). Gli scarichi idrici e la qualità delle acque dellarea industriale di Porto Marghera. Venice: MAG-ACQUE.

Marcomini, A., Zanette, M., D’Andrea, F., and Della Sala, S. (1997). Diossine, Salute E Ambiente. Venezia: Arsenale Editrice.

Mayer, L. M., Weston, D. P., and Bock, M. J. (2001). Benzo[a]pyrene and zinc solubilization by digestive fluids of benthic invertebrates-a cross-phyletic study. Environ. Toxicol. Chem. 20, 1890-1900. doi: 10.1002/etc.5620200906

McFarland, V. A., Lutz, C. H., and Reilly, F. J. (1994). Bioaccumulation Data and Analysis for Selected Contaminants in Sediments and Biota of the New York Bight Apex Mud dump Reference Site. New York, NY: U.S Army Engineer District.

Molinaroli, E., Guerzoni, S., De Falco, G., Sarretta, A., Cucco, A., Como, S., et al. (2009). Relationships between hydrodynamic parameters and grain size in two contrasting transitional environments: the Lagoons of Venice and Cabras, Italy. Sediment. Geol. 219, 196-207. doi: 10.1016/J.SEDGEO.2009.05.013

Nesto, N., Cassin, D., and Da Ros, L. (2010). Is the polychaete, Perinereis rullieri (Pilato 1974), a reliable indicator of PCB and PAH contaminants in coastal sediments? Ecotoxicol. Environ. Saf. 73, 143-151. doi: 10.1016/J.ECOENV.2009. 09.004

Nunes, M., Marchand, P., Vernisseau, A., Bizec, B., Le Ramos, F., and Pardal, M. A. (2011). PCDD/Fs and dioxin-like PCBs in sediment and biota from the Mondego estuary (Portugal). Chemosphere 83, 1345-1352. doi: 10.1016/J. CHEMOSPHERE.2011.02.081

Opperhuizen, A., and Sijm, D. T. H. M. (1990). Bioaccumulation and biotransformation of polychlorinated dibenzo- $\mathrm{p}$-dioxins and dibenzofurans in fish. Environ. Toxicol. Chem. 9, 175-186. doi: 10.1002/etc.5620090207

Pastershank, G. M., Muir, D. C. G., and Fairchild, W. L. (1999). Accumulation and depuration of 2,3,7,8-tetrachlorodibenzofuran and octachlorodibenzo- $p$ dioxin by caddisfly larvae (Hydropsyche bidens (ross)) in miniature laboratory streams. Environ. Toxicol. Chem. 18, 2352-2360. doi: 10.1002/etc. 5620181032

Pickard, S. W., and Clarke, J. U. (2008). Benthic bioaccumulation and bioavailability of polychlorinated dibenzo-p-dioxins/dibenzofurans from surficial lake ontario sediments. J. Great Lakes Res. 34, 418-433. doi: 10.3394/0380-1330(2008)34[418:bbabop]2.0.co;2

Picone, M. (2006). Impiego di una batteria di saggi ecotossicologici nel monitoraggio della qualità dei sedimenti della Laguna di Venezia. Venezia: Università Ca’ Foscari Venezia.
Picone, M., Bergamin, M., Arizzi Novelli, A., Noventa, S., Delaney, E., Barbanti, A., et al. (2008). Evaluation of Corophium orientale as bioindicator for Venice Lagoon: sensitivity assessment and toxicity-score proposal. Ecotoxicol. Environ. Saf. 70, 174-184. doi: 10.1016/j.ecoenv.2006.06.005

Picone, M., Bergamin, M., Delaney, E., Volpi Ghirardini, A., and Kusk, K. O. (2018). Testing lagoonal sediments with early life stages of the copepod Acartia tonsa (Dana): an approach to assess sediment toxicity in the Venice Lagoon. Ecotoxicol. Environ. Saf. 147, 217-227. doi: 10.1016/j.ecoenv.2017. 08.042

Picone, M., Bergamin, M., Losso, C., Delaney, E., Arizzi Novelli, A., and Volpi Ghirardini, A. (2016). Assessment of sediment toxicity in the Lagoon of Venice (Italy) using a multi-species set of bioassays. Ecotoxicol. Environ. Saf. 123, 32-44. doi: 10.1016/j.ecoenv.2015.09.002

Pruell, R. J., Rubinstein, N. I., Taplin, B. K., LiVolsi, J. A., and Bowen, R. D. (1993). Accumulation of polychlorinated organic contaminants from sediment by three benthic marine species. Arch. Environ. Contam. Toxicol. 24, 290-297. doi: 10.1007/BF01128727

Pruell, R. J., Taplin, B. K., McGovern, D. G., McKinney, R., and Norton, S. B. (2000). Organic contaminant distributions in sediments, polychaetes (Nereis virens) and American lobster (Homarus americanus) from a laboratory food chain experiment. Mar. Environ. Res. 49, 19-36. doi: 10.1016/S0141-1136(99) 00046-X

Raccanelli, S., Frangipane, G., and Libralato, S. (2007). Serum levels of PCDDs, PCDFs and dioxin-like PCBs in relation to different exposures in Italian adult men. Organohalogen Compd. 69, 1934-1937.

Raccanelli, S., Libralato, S., Favotto, M. (2008). On the detoxification of benthic bivalves contaminated by POPs: insights from experimental and modelling approaches. Environ. Chem. Lett. 6, 251-258. doi: 10.1007/s10311-007-0127-9

Raccanelli, S., Pastres, R., Favotto, M., and Vio, P. (2004). Correlation between POPs in sediment and edible bivalve in the lagoon of Venice and estimation of the daily intake. Organohalogen Compd. 66, 1823-1828.

Ruus, A., Daae, I. A., and Hylland, K. (2012). Accumulation of polychlorinated biphenyls from contaminated sediment by Atlantic cod (Gadus morhua): direct accumulation from resuspended sediment and dietary accumulation via the polychaete Nereis virens. Environ. Toxicol. Chem. 31, 2472-2481. doi: 10.1002/ etc. 1973

Ruus, A., Schaanning, M., Øxnevad, S., and Hylland, K. (2005). Experimental results on bioaccumulation of metals and organic contaminants from marine sediments. Aquat. Toxicol. 72, 273-292. doi: 10.1016/j.aquatox.2005.01.004

Scaps, P. (2002). A review of the biology, ecology and potential use of the common ragworm Hediste diversicolor (O.F. Müller) (Annelida: Polychaeta). Hydrobiologia 470, 203-218. doi: 10.1023/A:1015681605656

Schell, J. D., Campbell, D. M., and Lowe, E. (1993). Bioaccumulation of 2,3,7,8tetrachlorodibenzo- $P$-dioxin in feral fish collected from a bleach-kraft paper mill receiving stream. Environ. Toxicol. Chem. 12, 2077-2082. doi: 10.1002/etc. 5620121115

Schrock, M. E., Barrows, E. S., and Rosman, L. B. (1997). Biota-to-sediment accumulation factors for TCDD and TCDF in worms from 28-day bioaccumulation tests. Chemosphere 34, 1333-1339. doi: 10.1016/S00456535(97)00430-X

Secco, T., Pellizzato, F., Sfriso, A., and Pavoni, B. (2005). The changing state of contamination in the Lagoon of Venice. Part 1: organic pollutants. Chemosphere 58, 279-290. doi: 10.1016/J.CHEMOSPHERE.2004.06.030

Sfriso, A., Facca, C., and Raccanelli, S. (2014). PCDD/F and dioxin-like PCB bioaccumulation by Manila clam from polluted areas of Venice lagoon (Italy). Environ. Pollut. 184, 290-297. doi: 10.1016/J.ENVPOL.2013.08.026

Shepard, F. P. (1954). Nomenclature based on sand-silt-clay ratios. J. Sediment. Res. 24, 151-158.

Sijm, D. T. H. M., Opperhuizen, A., and Wever, H. (1993). Congener-specific biotransformation and bioaccumulation of PCDDs and PCDFs from fly ash in fish. Environ. Toxicol. Chem. 12, 1895-1907. doi: 10.1002/etc.56201 21016

Sizmur, T., Canário, J., Gerwing, T. G., Mallory, M. L., and O’Driscoll, N. J. (2013). Mercury and methylmercury bioaccumulation by polychaete worms is governed by both feeding ecology and mercury bioavailability in coastal mudflats. Environ. Pollut. 176, 18-25. doi: 10.1016/J.ENVPOL.2013.01.008

Stringer, R. L., Costner, P., and Johnston, P. A. (1995). PVC manifacture as a source of PCDD/Fs. Organohalogen Compd. 24, 119-123. 
Swerev, M., and Ballschmiter, K. (1989). Pattern analysis of PCDDs and PCDFs in environmental samples as an approach to an occurrence source correlation. Chemosphere 18, 609-616. doi: 10.1016/0045-6535(89)90 $173-2$

Tagliapietra, D., Sigovini, M., and Volpi Ghirardini, A. (2009). A review of terms and definitions to categorise estuaries, lagoons and associated environments. Mar. Freshw. Res. 60, 497-509. doi: 10.1071/MF08088

Tagliapietra, D., and Volpi Ghirardini, A. (2006). Notes on coastal lagoon typology in the light of the EU water framework directive: Italy as a case study. Aquat. Conserv. Mar. Freshw. Ecosyst. 16, 457-467. doi: 10.1002/aqc.768

Van den Berg, M., Birnbaum, L. S., Denison, M., De Vito, M., Farland, W., Feeley, M., et al. (2006). The 2005 World Health Organization reevaluation of human and mammalian toxic equivalency factors for dioxins and dioxin-like compounds. Toxicol. Sci. 93, 223-241. doi: 10.1093/toxsci/ $\mathrm{kfl} 055$

van der Oost, R., Beyer, J., and Vermeulen, N. P. (2003). Fish bioaccumulation and biomarkers in environmental risk assessment: a review. Environ. Toxicol. Pharmacol. 13, 57-149. doi: 10.1016/S1382-6689(02)00126-6

Volpi Ghirardini, A., Arizzi Novelli, A., and Tagliapietra, D. (2005). Sediment toxicity assessment in the Lagoon of Venice (Italy) using Paracentrotus lividus (Echinodermata: Echinoidea) fertilization and embryo bioassays. Environ. Int. 31, 1065-1077. doi: 10.1016/j.envint.2005.05.017

Volpi Ghirardini, A., Cavallini, L., Delaney, E., Tagliapietra, D., Ghetti, P. F., Bettiol, C., et al. (1999). H. diversicolor, N. succinea and P. cultrifera (Polychaeta: Nereididae) as bioaccumulators of cadmium and zinc from sediments: preliminary results in the Venetian lagoon (Italy). Toxicol. Environ. Chem. 71, 457-474. doi: 10.1080/02772249909358815
Volpi Ghirardini, A., Delaney, E., Tagliapietra, D., Arizzi Novelli, A., Frangipane, G., Marchetto, D., et al. (2004). "Hediste diversicolor (Polychaeta: Nereididae) as effective biomonitor of POPs (PCBs and organochloride pesticides) for lagoonal sediments," in Proceedings of the ECSA-ERF 38th Symposium, Rouen.

Voparil, I. M., and Mayer, L. M. (2000). Dissolution of sedimentary polycyclic aromatic hydrocarbons into the lugworm's (Arenicola marina) digestive fluids. Environ. Sci. Technol. 34, 1221-1228. doi: 10.1021/es990885i

Zheng, S., Chen, B., Qiu, X., Lin, K., and Yu, X. (2013). Three novel cytochrome P450 genes identified in the marine polychaete Perinereis nuntia and their transcriptional response to xenobiotics. Aquat. Toxicol. 134-135, 11-22. doi: 10.1016/J.AQUATOX.2013.02.009

Zonta, R., Botter, M., Cassin, D., Pini, R., Scattolin, M., and Zaggia, L. (2007). Sediment chemical contamination of a shallow water area close to the industrial zone of Porto Marghera (Venice Lagoon, Italy). Mar. Pollut. Bull. 55, 529-542. doi: 10.1016/j.marpolbul.2007.09.024

Conflict of Interest: The authors declare that the research was conducted in the absence of any commercial or financial relationships that could be construed as a potential conflict of interest.

Copyright (c) 2020 Picone, Delaney, Tagliapietra, Guarneri and Volpi Ghirardini. This is an open-access article distributed under the terms of the Creative Commons Attribution License (CC BY). The use, distribution or reproduction in other forums is permitted, provided the original author(s) and the copyright owner(s) are credited and that the original publication in this journal is cited, in accordance with accepted academic practice. No use, distribution or reproduction is permitted which does not comply with these terms. 